\title{
LABOR SUPPLY EFFECTS OF OCCUPATIONAL REGULATION: EVIDENCE FROM THE NURSE LICENSURE COMPACT
}

\author{
Christina DePasquale \\ Kevin Stange \\ Working Paper 22344 \\ http://www.nber.org/papers/w22344 \\ NATIONAL BUREAU OF ECONOMIC RESEARCH \\ 1050 Massachusetts Avenue \\ Cambridge, MA 02138 \\ June 2016
}

We are grateful to Thomas Buchmueller, Sam Kleiner, Francine Lafontaine, Yesim Orhun, Sarah Stith, and seminar participants at the Rollins School of Public Health, University of Virginia School of Law, Ford School of Public Policy, ASHEcon 2014, APPAM 2014, ASSA Annual Meetings 2016, and SOLE 2016 for helpful comments and suggestions. The views expressed herein are those of the authors and do not necessarily reflect the views of the National Bureau of Economic Research.

NBER working papers are circulated for discussion and comment purposes. They have not been peer-reviewed or been subject to the review by the NBER Board of Directors that accompanies official NBER publications.

(C) 2016 by Christina DePasquale and Kevin Stange. All rights reserved. Short sections of text, not to exceed two paragraphs, may be quoted without explicit permission provided that full credit, including ( $)$ notice, is given to the source. 
Labor Supply Effects of Occupational Regulation: Evidence from the Nurse Licensure Compact Christina DePasquale and Kevin Stange

NBER Working Paper No. 22344

June 2016

JEL No. J21,J44,J61

\title{
ABSTRACT
}

There is concern that licensure requirements impede mobility of licensed professionals to areas of high demand. Nursing has not been immune to this criticism, especially in the context of perceived nurse shortages and large expected future demand. The Nurse Licensure Compact (NLC) was introduced to solve this problem by permitting registered nurses to practice across state lines without obtaining additional licensure. We exploit the staggered adoption of the NLC to examine whether a reduction in licensure-induced barriers alters the nurse labor market. Using data on over 1.8 million nurses and other health care workers we find no evidence that the labor supply or mobility of nurses increases following the adoption of the NLC, even among the residents of counties bordering other NLC states who are potentially most affected by the NLC. This suggests that nationalizing occupational licensing will not substantially reduce labor market frictions.

\author{
Christina DePasquale \\ Emory University \\ 1602 Fishburne Dr. \\ Atlanta, GA, 30322 \\ depasquale@emory.edu \\ Kevin Stange \\ Gerald R. Ford School of Public Policy \\ University of Michigan \\ 5236 Weill Hall \\ 735 South State Street \\ Ann Arbor, MI 48109 \\ and NBER \\ kstange@umich.edu
}




\section{Introduction}

Occupational licensing is pervasive in the US and Europe. Nearly $29 \%$ of the US workforce requires a federal- or state-granted license to practice or work in their occupation (Kleiner and Krueger 2008; Thornton and Timmons, 2013) and over 800 occupations are licensed by at least one state (Kleiner 2000). While licensing aims to protect consumers and ensure safety by certifying provider quality, it may also create rents for incumbent members of the licensed occupation by restricting supply.

One mechanism through which licensing could restrict supply is by impeding geographic mobility. Since licensing and certification is primarily at the state level, workers typically must obtain separate licenses for each state in which they work and a new license whenever they move between states. Such barriers to mobility may prevent workers from seeking jobs across state lines, misallocating workers geographically and depressing employment and labor force participation. Moreover, licensed professionals may be less likely to move to areas of high demand. Such barriers may be problematic, as interstate migration is historically an important mechanism through which labor markets adjust to regional shocks (Blanchard and Katz, 1992) and recent analysis suggests mobility’s role has decreased (Dao, Furceeri, Loungani, 2014). More generally, licensing may have contributed to the steady reduction in internal migration in the U.S. over the past several decades, but this channel not been explored (Molloy, Smith, Wozniak, 2011).

Policy-makers have recently taken note of the potential economic and human costs of licensing-induced barriers. The Department of Treasury Office of Economic Policy, the Council of Economic Advisers, and the Department of Labor recently released a report detailing best practices for occupational licensing (U.S. Department of the Treasury Office of Economic Policy, Council of Economic Advisers, and the Department of Labor, 2015). The report acknowledges that while licensing improves service quality, it can create economic inefficiencies by restricting worker mobility, reducing employment opportunities for excluded workers, and increasing costs to consumers. Military families are particularly vulnerable, both because of their high rates of involuntary movement and the large share of military spouses that are teachers and registered nurses, both of which require licenses (U.S. Department of Treasury and U.S. Department of Defense, 2012). The report suggests that states should try to harmonize requirements and recognize licenses from other states.

In this paper, we examine the impact of such a policy on the labor market for nurses, 
exploiting a unique policy change that made it substantially easier for nurses to work and, to a lesser extent, move across state lines. Nursing is an important occupation to focus on, as the availability of nurses is important for community health, hospital care, and disaster relief. Furthermore, an already acute nursing shortage is expected to increase over the next decade, as more nurses retire and the aging population increases demand for health care services (Buerhaus, Staiger, Auerbach, 2009). Insurance expansions embodied in the Affordable Care Act may only exacerbate this shortage. Removing licensing barriers is one mechanism to better utilize the existing supply of trained nurses. The ability for technology to improve health care delivery is also hampered by cross-state licensing barriers for health care workers, which makes telemedicine difficult legally (Sulentic 1991) as health providers must be licensed in the states in which their patients reside.

Surprisingly, compelling evidence on the impact of licensing on the geographic scope of labor markets is thin. Several studies, dating back a half-century, document a cross-sectional correlation between licensing restrictions and interstate mobility of professionals (Holen, 1965; Pashigian, 1979; Conrad and Dolan,1980; Kleiner, Gay, and Greene, 1982). A challenge with this cross-sectional analysis is that licensure practices may correlate with other unobserved state-level attributes that influence migration. Peterson, Pandya, LeBang (2014) address this problem by exploiting changes in residency training requirements for immigrant physicians within states over time, finding that states that impose more stringent requirements receive fewer immigrant physicians. We add to this literature by examining a recent policy change, the Nurse Licensure Compact (NLC), with a compelling research design that lets us control for several sources of bias that may confound previous estimates. This study is the first to provide direct evidence on the likely effects of nationalizing licensure for a large and important occupation.

The NLC was introduced to reduce licensing burdens by permitting registered nurses living in member states to practice across state lines. It also made licensure easier to obtain for nurses moving between member states. Twenty-five states have implemented the NLC since its inception in 2000 and another six states currently have NLC legislation pending. We exploit the staggered adoption of the NLC across states and over time to examine whether a reduction in licensure-induced barriers is associated with a greater labor force participation and hours worked, greater likelihood of cross-state commuting, and longer travel time to work among nurses. We estimate difference-in-differences models, comparing nurses in states adopting the NLC to those 
in states that do not. While this controls for time-invariant characteristics of states that may correlate with both labor market outcomes and licensure laws, state-specific time-varying factors may still bias estimates of the policy. A unique feature of our setting is that we are able to use non-nurse health workers (who are not affected by the NLC) to construct triple difference models to control for any health care labor market changes that may happen to correlate with NLC adoption. We find that this feature is important, as results from the triple difference models are different than those from the basic difference-in-differences approach for some outcomes, suggesting a time-varying source of bias in the latter. Since many workers may be unaffected by the Compact since they do not live near another Compact state, we also implement a similar research design focused on residents of counties that border other states. Even within NLC states, some counties share a border with another NLC state, while others do not.

Using data on over 1.8 million nurses and other health care workers from the 1990 and 2000 Census and the 2001-2012 American Community Surveys, we find no effect of NLC adoption on a variety of labor market outcomes of nurses such as labor force particpation, employment levels, hours worked, earnings, and likelihood of working across state lines. This null effect persists even when focusing on those workers most likely to be affected by the NLC. That is, we estimate the treatment effect of living in a border county in a Compact state that also borders another Compact state and find no effect on the same labor market outcomes. We do find positive effects of NLC adoption on travel time to work for nurses living in MSAs, but discount this finding as we do not see a similar increase those living in border counties. We also find minimal effect of the NLC on workers' overall likelihood of moving across state lines, though estimates specifically for young and mobile workers are consistent with greater mobility rates, though these estimates are imprecise. We supplement our main analysis with event-study models to test if there are systematic pre-trends in workforce characteristics or labor supply outcomes before the introduction of the NLC. We find little evidence to suggest that pre-trends may be biasing our difference-in-difference estimates nor is there any evidence that NLC adoption is associated with greater labor supply. Finally, we see no effect of NLC exposure on the aggregate number of nurse hours worked at hospitials using hospital-level data from the American Hospital Association survey.

The paper is organized as follows. In the next section, we provide a simple conceptual framework, background on nurse licensing and the NLC, and a review of the literature. Next, our 
methods and data are described in Section 3 and results are discussed in Section 4. Finally, Section 5 offers concluding remarks.

\section{Framework and Background}

\section{A. Conceptual Framework}

We frame our analysis with a simple static model of individuals' joint work and migration decisions. The labor market is characterized by three geographic areas: the current home state $(\mathrm{H})$, an area in a nearby state that is commutable without moving $(\mathrm{N})$, and a distant labor market in another state that would require moving to work in $(F)$. Workers receive wage offers in the three markets each period $\left\{W_{i, H}, W_{i, N}, W_{i, F}\right\}$. Workers also receive random draws of the utility associated with living in the home state $(\mathrm{H})$ and the alternative far state $(\mathrm{F}):\left\{e_{i, H}, e_{i, F}\right\}$. These shocks include things like job offers received by spouses, health shocks of distant family members, and other non-job factors influencing mobility decisions.

Commuting to a nearby state requires commute cost $D_{N}$, whereas moving to the far state imposes a moving cost $D_{F}$. Finally, professionals working in the nearby state or moving to the far state must pay a cost L to obtain an occupational license in that new state before they can work. We view the adoption of the Compact as an elimination of L, since it permits nurses to work across state lines and to be easily licensed after moving between Compact states. This will have several impacts on the migration and labor supply choices of licensed professionals:

- Migration. Workers will move if $\max \left\{W_{i F}-D_{F}-L, 0\right\}+e_{i F}>\max \left\{W_{i H}, W_{i N}-D_{N}-\right.$ $L, 0\}+e_{i H}$. Note that moving may be desirable even if the financial returns are not high if the utility draw associated with moving is high enough. For instance, workers may move to take care of an elderly relative or due to a spousal job change. We expect that elimination of L most likely increases cross-state migration. However, a reduction of licensing barriers also increases the value of working from the home state (by increasing the value of cross-state commuting), which may partially diminish the incentive to move.

- Employment and labor supply. Workers choosing to remain in the home state will work if $\max \left\{W_{i H}, W_{i N}-D_{N}-L\right\}>0$ while those who choose to move to the new state will work if $W_{i F}-L>0$. Thus all workers, regardless of their tenure in a given locale, will have a greater incentive to work when cross-state licensing barriers are minimal, though the specific mechanism is different. Non-mobile workers will increase employment by 
accepting opportunities in nearby states (or telecommuting). Nurses that moved for non-job reasons (e.g. a high $e_{i F}$ ) will be more likely to work if $\mathrm{L}$ is low. We generalize this intuition to other measures of labor supply on the extensive (e.g. labor force participation) and intensive (e.g. hours worked, wage income received last year) margins.

- Cross-state commuting. Workers that do not move will work in a nearby state (rather than the current home state) if $W_{i N}-D_{N}-L>W_{i H}$. Thus reducing licensing barriers should directly increase rates of cross-state commuting.

- Aggregate labor supply. Finally, we examine measures of aggregate use of nurses (e.g. total hours worked at hospitals) as a summary measure of the combined effects of migration and extensive/intensive labor supply responses. Since a reduction in L reduces the hiring costs associated with licensed workers, we expect aggregate utilization of nurses to increase.

We examine each of these aspects in our empirical work. There are other aspects that we do not consider but are important to keep in mind. First, the current licensing regime may affect the decision to enter the nursing profession. Second, the reduction or elimination of licensing barriers may change the shape of the labor supply curve, altering the wage and employment consequences of local labor demand shocks. More specifically, we would expect the labor supply curve to flatten and to become more elastic. Furthermore, as the NLC is adopted, we may see a reduction in the variability in wages due to this flatter supply and a consequent diminishing effect of demand shocks on wages. While exploring these predictions is beyond the scope of this paper, we plan to do so in subsequent work.

\section{B. Nurse Licensure and the Nurse Licensure Compact}

\section{Obtaining a license}

In 1947, New York became the first state to require mandatory licenses for nurses. Today, every state requires a nurse to obtain a license to practice within the state (Benefiel, 2011). Obtaining a license typically requires a degree from an accredited program (certificate, associates degree, or bachelor's degree), passing a licensing examination, and meeting requirements that are set by each state individually. 
Until 1994, exam requirements differed across states. With a call for uniformity across states (Barnum, 1997), the National Council of States Boards of Nursing ntroduced the computer adaptive test known as the National Council Licensure Examination (NCLEX) for registered nurses and licensed practical nurses.

Besides an examination, there are monetary costs associated with obtaining an initial license in a state. For example, in the state of California, the examination registration fee is $\$ 200$ plus the fee for verification of licensure (\$60) plus the application fee of $\$ 100$.

When an already licensed nurse moves to a new state he or she is required to apply for "licensure by endorsement" which allows for the transferring of state licenses. The costs associated with "licecnsure by endorsement" varies across states in terms of time and money. For instance, application fees range from under $\$ 50$ in Colorado to over $\$ 200$ in Florida. These application fees include a temporary license while nurses wait for their permanent license to be issued. The wait time and validity of these licenses also varies substantially across states. Texas nurses need only wait 10 days for a temporary licensed to be issued yet in California nurses may need to wait up to 6 weeks in order to begin practicing. Georgia, on the other hand, does not issue any temporary licenses. These temporary licenses are typically valid anywhere from 30 days in Virginia to as much as 6 months in California, North Carolina, and Kentucky. Nurses are usually not required to retake the National Council Licensure Examination (NCLEX) if they have already passed an equivalent exam in another state (U.S. Department of the Treasury, U.S. Department of Defense, 2012).

\section{The Nurse Licensure Compact}

The Nurse Licensure Compact (NLC) was first passed in 1999 by Utah and Arkansas, and first implemented by Maryland, Texas, Utah, and Wisconsin in 2000. The compact allows a nurse licensed in one NLC-member state to practice in other NLC states without obtaining a separate license for the other state. Each state that is a member mutually recognizes other member states. Since its introduction, 25 states have implemented the Nurse Licensure Compact and another six states currently have NLC legislation pending. ${ }^{1}$ Figure 1 depicts the number of states that are part of the NLC over time. While about half of the states joined the Compact in its first two years of existence, an average of 1-2 states per year have continued to join the compact since. Figure 2

${ }^{1}$ Table A1 in the Appendix lists the date of implementation for each Compact state. 
identifies the Compact states in 2000 (its first year) and 2012 (the last year of our analysis). It is worth noting that each member state currently has another member state that is adjacent to it except for Rhode Island (although Massachusetts currently has legislation pending).

In order for a state to join the NLC, they must meet four requirements. First, the bill language drafted by state legislators must mirror that of the "NLC Model Legislation," which is provided by the National Council of State Boards of Nursing. The model legislation is attached as Appendix B. Second, the state legislature must pass the legislation. Third, the State Board of Nursing must implement the Compact. ${ }^{2}$ Finally, the state must pay $\$ 3000$ per year to keep their membership in the NLC active. The NLC applies to registered nurses (RNs), licensed practical (LPNs) and licensed vocational nurses (LVNs) only. ${ }^{3}$ To be eligible for a multistate license, a nurse's primary state of residence must be a compact-member state. As long as a nurse declares a compact state as a primary state of residence and the nurse is in good standing, the license automatically becomes a multistate license and the nurse can practice physically or electronically in other compact states. If a nurse works in a compact states but lives (i.e. has a primary state of residence) in a non-compact state, he/she is not eligible for a multistate license.

If a compact-eligible nurse permanently relocates to another compact state, that is, the nurse obtains a new driver's license, votes, or files taxes in another state, the nurse must apply for licensure by endorsement and declare the new state as his/her primary state of residence. This must be completed within 30 to 90 days of moving (depending on the state), although some states are currently in the process of amending the amount of time a nurse may practice with a license issued by another state. By contrast, nurses moving from or to a non-Compact state must generally obtain a license in the new state before they can practice in the new state. Thus movement between Compact states provides nurses with a grace period of one to three months in which they can work that is not experienced by residents of non-Compact states. Figure 3 provides a flow chart explaining the process through which a new nursing graduate obtains either a single-state or multi-state license.

Advocates of the NLC cite five main benefits. First, The NLC clarifies the authority to practice for many nurses currently engaged in telenursing or interstate practice. Second, the NLC provides greater mobility for nurses. (They cite the U.S. Department of Health and Human

2 The takes approximately one year from the time the bill is passed.

3 Advanced Practical Registered Nurses (APRNs) do not fall under the NLC, but instead have their own separate APRN Compact that provides for a multistate license. 
Services Health Resources and Services Administration’s 2010 report, “Health Licensing Board Report to Congress” as evidence.) Third, the NLC improves access to licensed nurses during a disaster or other times of great need for qualified nursing services. Fourth, the NLC improves access to nursing care. Finally, the NLC enhances discipline and information-sharing among participating states.

\section{Related Literature on Occupational Licensing}

Relative to its prevalence, there is little research on the labor market effects of occupational licensing and restrictions. ${ }^{4}$ Prior work on the labor market effects have focused primarily on wages, generally finding that restrictive licensing is associated with higher wages (Thornton and Timmons, 2013). ${ }^{5}$ Using unique data on the dental health of Air Force recruits, Kleiner and Kudrle (2000) find that restrictive licensing increases dental prices and earnings of dentists. Weeden (2002) finds that licensed occupations have higher wages, controlling for a whole host of other individual- and occupation-specific determinants of earnings, such as the skill and task requirements of the job and education level. Kugler and Sauer (2005) find very large returns to acquiring an occupational license among immigrant physicians in Israel. A unique feature of their study is that they exploit variation in licensing that is driven by a policy that assigns immigrant physicians to different re-training regimes based on their experience. This represents an advance over much of the prior literature, which simply compared licensed with similar unlicensed occupations. More recently, Kleiner and Park (2010) and Kleiner, Marier, Won Park, and Wing (2011) find that changes in occupational regulations for dental hygienists and nurse practitioners, respectively, increase wages for these occupations.

While the evidence of licensing's effect of wages is robust, there is little direct evidence on whether reduced labor supply or mobility is the primary channel. Several studies document a cross-sectional correlation between licensing restrictions and interstate mobility. Fifty years ago, Holen (1965) found that the in-migration of dentists, lawyers, judges, physicians, and surgeons was higher in states that had easier re-licensing. Pashigian (1979) found that the in-migration of

\footnotetext{
${ }^{4}$ Kleiner (2000) and Kleiner (2006) provide an overview of much of the theoretical and empirical literature on occupational regulation.

5 There is also a very small literature on the effect of licensing on provider and service quality (Kleiner and Kudrle 2000; Angrist and Guryan, 2003; Sass, 2015) and output markets (Schaumans and Verboven, 2008; Hotz and Xiao, 2011; Kleiner, Marier, Won Park, and Wing 2011; Stange, 2014).
} 
lawyers was hampered by restrictive licensing. Kleiner, Gay, and Greene (1982) examined mobility in 14 different occupations as it relates to licensure restrictiveness. They found that states with less restrictive licensing and easier endorsement from other states have higher rates of in-migration. Thus restrictive licensing creates a barrier to mobility, misallocating workers across states. Thornton and Timmons (2013) add to this evidence by showing that the occupational regulation of massage therapist through state licensing appears to reduce the number of massage therapists, while Zapletal (2014) finds no effect of occupational licensing on the number of cosmetologists. Conrad and Dolan (1980) showed that reciprocity rules limit the migration of professions into restrictive states. A challenge with these cross-sectional analyses is that licensure practices may correlate with other state-level attributes that influence migration (beyond the variables controlled for). Peterson, Pandya, LeBang (2014) address this problem by exploiting changes in residency training requirements for immigrant physicians within states over time, finding that states that impose more stringent requirements receive fewer immigrant physicians. Similarly, Federman, Harrington, and Krynski (2006) find that states requiring English language proficiency have fewer Vietnamese manucurists. Work standards - not just occupational regulations - also may influence mobility. Bloomfield, Bruggemann, Christensen, and Leuz (2015) find that the harmonization of accounting standards across EU countries increased cross-country mobility of accountants in the EU by a substantial amount.

We add to this literature in four ways. First, the nature of the policy change which affected nurses but not other health workers permits us to estimate triple difference models, which control for time-varying sources of demand for health care workers that may happen to correlate with NLC adoption. Second, our analysis of residents of border counties permits us to narrowly focus on the individuals most likely to be affected by exposure the change in licensure regime. Third, we study a very recent policy change, whereas most of the literature relies on data from forty years ago, when labor market institutions and structures may have been quite different. Finally, we examine nurses, who are the second largest licensed profession behind teachers (Kleiner 2000) and whose supply and geographic distribution are targets of extensive policy deliberation.

\section{Empirical Approach}

\section{A. Worker Data and Samples}


We analyze nurses and other health care workers surveyed in the public use micro surveys from the 1990 and 2000 U.S. Census and the 2001 to 2012 American Community Survey (ACS) harmonized by IPUMS-USA. The ACS is an ongoing survey that provides yearly information about communities in the years between the Decennial Censuses. Detailed information is collected about age, sex, race, income, education, where one works, commuting distance, where one lives, as well as occupation. Current labor force participation and employment status are collected, as is the usual hours worked and wage or salary income from the prior year. The Census data provides similar information, albeit on a ten-year basis and for larger samples. While the ACS helps provide additional information in the years when states are joining the NLC, the Census data provides information before the advent of the NLC. Both identify Registered Nurses (RNs) and Licensed Practical Nurses (LPNs) specifically, who are both subject to the NLC. ${ }^{6}$

Our data include all workers in health occupations, including nurses, physicians, medical assistants, home health aids, and several other smaller occupational categories. ${ }^{7}$ Non-nurse health care workers are not subject to the Nurse Licensure Compact but work in similar settings and thus potentially form a good control group with which to compare RNs and LPNs. Locational information allow us to identify whether an individual lives and/or works in a NLC state as well as whether they live in an MSA. Our full sample includes 1.8 million health workers, about 38\% of which are nurses.

For some of our analysis we focus on individuals residing in counties on state borders. Of the 3142 counties in the U.S., approximately one-third border at least one other state. However, the county of residence is identifiable for only a subset of the sample in the Census/ACS and only since 2005. Specifically, respondents are assigned to census-constructed areas of 100,000 residents called Public Use Micro Areas (PUMAs), which do not cross state lines. Thus county of residence is identifiable in cases where the PUMA uniquely identifies a county (i.e. county is

${ }^{6}$ The ACS sample changes over time. As described at https://usa.ipums.org/usa/sampdesc.shtml, the 2001 through 2004 ACS samples were 1 in 232 or 1 in 261 sample of the U.S. population not in group quarters, as the ACS was being rolled out and tested in those years. The 2005 ACS is a $1 \%$ sample of the population excluding group quarters. The 2006 and later ACS are 1\% samples of the population including group quarters. The 2001-2004 samples do not include geographic identifiers lower than the state.

${ }^{7}$ Occupation is collected for all persons age 16+ who had worked within the previous five years, excluding new workers with no experience. Since our sample is based on occupation, we necessarily exclude individuals who have not worked for five years. Thus, our analysis should be interpreted as conditional on having some reasonable amount of attachment to the labor force. 
coterminous with a single PUMA or is composed of multiple PUMAs that do not extend into other counties). Approximately 380 counties are identifiable in our sample each year, accounting for $57 \%$ of the full sample. Across all years, the sample includes 189 border counties in 44 states. Identifiable counties are necessarily larger than average, so conclusions from our border county analysis may not necessarily apply to residents of small or rural communities. Our border county sample represents $21 \%$ of the full sample and includes 348,486 health workers, $37 \%$ of which are nurses.

Table 1 provides summary statistics for our full and border county samples of nurses and all health workers across all years. ${ }^{8}$ Statistics are shown separately by whether the individual currently lives in a compact state. Across all states and years, 3-4\% of nurses and other health workers commute across state lines to work, with an average travel time of 23 to 24 minutes (among those that work). Cross-state commuting and travel time are both higher among workers living in Compact states. Eighty-seven percent of the nurses in the sample are currently in the labor force, with almost all of those who are labor force participants being currently employed, working an average of 34 hours and earning \$32,689 the previous year. ${ }^{9}$ Unsurprisingly, residents of border counties are much more likely to commute across state lines to work, with the average rising to $6 \%$ for all health workers and $7 \%$ for nurses. Labor force participation, earnings, and travel time to work is also higher among these individuals, though hours worked are quite similar to the full sample.

Interestingly, nurses are more mobile and have greater labor force participation rates when the Compact is in place. This pattern is most striking for nurses in border counties: individuals residing in and bordering a Compact state are about twice as likely to commute across state lines than individuals that do not. However, many of these patterns are also observed for the broader sample of health workers, even though two-thirds of them should be unaffected by the Compact. Furthermore, there are some observed differences between nurses and other health workers residing in Compact states or treated counties that could also relate to labor market outcomes. Workers exposed to the NLC are slightly older, have smaller families, and are less likely to be immigrants (naturalized citizens or not). These differences underscore the need to more carefully

${ }^{8}$ The summary statistics do not yet include the ACS samples from 2001 to 2005, so differ slightly from our estimation sample.

${ }^{9}$ Nurses have among the lowest unemployment rates of any occupation. The implied unemployment rate of $2 \%$ in our sample is consistent with official rates reported by the Bureau of Labor Statistics. 
control for observed and unobserved characteristcs of workers and locations that may correlate with NLC exposure.

\section{B. Hospital Data and Sample}

To complement our worker-level analysis, we use data from the American Hospital Association's (AHA) Annual Survey to look at changes in the number of nurses and nurses per hospital admission at the hospital-level before and after the compact controlling for hospital characteristics that effect demand for labor. The AHA annual survey provides data for $98 \%$ of US hospitals, including location, employment levels for certain occupations, ownership status, number of beds, admissions, patient days, and information on hospital system affiliation. The full sample of hospitals for the years 1995-2009 contains 93,463 hospital-year observations. The survey includes hospitals outside the 50 United States in Guam, American Samoa, the Marshall Islands, Puerto Rico, and the U.S. Virgin Islands. After restricting to hospitals in the 50 states, we are left with 92,488 hospital-year observations and 7,727 individual hospitals.

Labor supply of RNs, LPNs, and Total Nurses (RNs + LPNs) are measured as the number of “full-time equivalent” employees. The number of full-time equivalent employees is calculated by summing the total number of hours worked by all employees of the same occupational category (e.g. registered nurse) over a 12 month period, divided by the normal number of hours worked by a fulltime employee for that same time period (typically regarded as 40 hours per week, but left to hospital discretion). Admissions data used are adjusted by the AHA for outpatient visits. Summary statistics for the AHA sample are presented in Appendix Table A6.

\section{Identification Strategy and Method}

The raw summary statistics suggest that nurses have greater labor supply and are more mobile when the NLC is in place. However, this raw correlation is unlikely to provide a good estimate of the causal effect of the policy on labor supply or worker mobility. Time trends, state characteristics, worker characteristics, or labor market shocks that happen to correlate with the presence of the NLC are likely to bias estimates of its effect. To address these, we exploit the fact that states adopted the NLC at different times and that it only pertained to nurses to construct several difference-in-difference estimates of the effect of exposure to the Compact. 


\section{State-Level Difference-in-Differences Analysis}

Our first approach is to compare changes in outcomes of nurses between states that adopted the NLC with those that did not during the same time period. We begin by estimating simple difference-in-differences models on the sample of registered and licensed practical nurses using regressions of the form:

$$
Y_{\text {ist }}=\beta_{0}+\beta_{1} \text { Treatment }_{\text {st }}+\beta_{x} X_{\text {ist }}+\gamma_{s}+\gamma_{t}+\varepsilon_{\text {ist }}
$$

Our dependent variable, $Y_{\text {ist }}$, is the outcome (indicators for labor force participation, employed, usual hours worked, log of wage or salary income, works in different state, log of commute time to work, indicator for moved to another state in next year) for individual $i$ residing in state $s$ during year $t$. We use two different measures of Treatment. The first, Compact ${ }_{s t}$, is simply an indicator for whether state $s$ is a compact state in year $t$. However, this simple indicator variable does not fully campute the dynamics of the policy change because the value of belonging to the Comapct depends on which other states have decided to join. For instance, the value of the Compact to Utah in 2000 (when only a few states were part of the Compact) was substantially less than in 2012 (when half of states were). To address this, we construct a second measure of treatment which equals the fraction of other states that are part of the compact, weighted by the share of workers the state receives from each sending state. If a state is not part of the compact, then the treatment is equal to zero. Specifically,

$$
\text { Treament }_{\text {st }}=\text { Compact }_{s t} * \sum_{k=1}^{K} \text { Compact }_{k t} * \text { Weight }_{k s}
$$

Where Weight $_{k s}$ is share of all the workers that move to state s from state $\mathrm{k}$ among all workers who move to state s. These weights are estimated using the 1990 and 2000 decennial census and represent five-year migration rates. This treatment estimated by this variable can be thought of in two ways. First, it is the effect of joining the Compact when all the other states have already joined. Second, it provides the effect of all the other states joining the Compact among states that already have joined. In practice, estimates using this continuous treatment variable are quite similar to a rescaling of the estimates obtained using the binary treatment, by a ratio of about 3. Figure 4 depicts this continous treatment variable for six select states. For early adopting states, such as 
Texas and Utah, much of the treatment variation occurs after adoption, as neighboring states enter the Compact. For later adopting states, such as New Mexico, treatment variation arises mostly in the first year of adoption.

Aggregate time trends in the prevalence of cross-state commuting and employment are accounted for by year fixed effects $\gamma_{t}$. State fixed effects control for average differences in commuting and employment prevalence across areas that may be related to the adoption of the NLC. For instance, states that typically have many nurses commuting across the border may have a greater incentive to join the compact. In some specifications, we also control for time-varying individual $X_{\text {ist }}$ characteristics, such as worker demographics that may influence outcomes and also happen to correlate with adoption of the compact. The coefficient of interest $\beta_{1}$ is the change in outcomes following the adoption of the NLC relative to the time pattern experienced by other states. Standard errors are clustered at the state level, to address the possibility that observations within states are not independent.

\section{Triple Difference Model}

The simple difference-in-differences specification assumes that outcomes for treatment and control states would trend similarly in the absence of treatment. Labor market trends and shocks could violate this assumption if, for instance, states adopt the NLC in anticipation of growing demand for nurses or as a response to declining supply. Several features of the NLC naturally facilitate variations on the basic specification to probe the validity of this main identifying assumption. Most importantly, we exploit the fact that only nurses (registered and licensed vocational/practical) are affected by the compact while other health professionals (physicians, medical assistants, etc.) are not to construct a triple difference estimator. We first estimated (1) on the sample of non-nurse health workers and test whether there is any "effect" on these workers when there should not be. We then explicitly use these workers as a control group, and estimate the following model of the form:

$$
Y_{\text {ist }}=\beta_{0}+\beta_{1} \text { Treatment }_{\text {st }}+\beta_{2} \text { Nurse }_{\text {ist }}+\beta_{3} \text { Treatment }_{\text {st }} * \text { Nurse }_{\text {ist }}
$$




$$
+\beta_{x} X_{i s t}+\gamma_{s}+\gamma_{t}+\varepsilon_{i s t}
$$

The coefficient on Treatment $t_{\text {st }}$ captures any change in commuting patterns among non-nurse health care workers that are correlated with NLC adoption. The coefficient on the interaction term Treatment $_{\text {st }} *$ Nurse $_{\text {ist }}$ captures the differential impact on nurses and is our coefficient of interest. This specification controls for any time-varying labor market shocks that similarly affect nurses and other health care workers.

\section{Event-study Analysis}

An alternative approach to ruling out violation of the key identifying assumption in D-in-D models is to look for evidence of differential trends between Compact and non-Compact states before the former enact the NLC. It is possible that there are systematic pre-trends in workforce characteristics and labor supply outcomes before the introduction of the NLC. To test for such pre-trends in several of our outcome variables we estimate event-study models, we estimate the following model for all registered nurses and licensed practical nurses:

$$
Y_{\text {ist }}=\beta_{0}+\sum_{n=-N}^{N} \operatorname{Compact}_{s t}^{n} \beta_{n}+\beta_{x} X_{\text {ist }}+\gamma_{s}+\gamma_{t}+\varepsilon_{\text {ist }}
$$

where $Y_{i s t}$, is the outcome for individual $i$ residing in state $s$ during year $t$. Compact $t_{i t}^{n}$ are a set of dummy variables indicating each observation's timing relative to the introduction of the compact. The omitted category is the year prior to the Compact's implementation. $X_{i s t}$ is a vector of demographic controls, $\gamma_{s}$ and $\gamma_{t}$ are state and time fixed-effects, respectively, and standard errors are clustered at the state level. We test for whether outcomes are trending even before the compact was enacted.

Finally, it is possible that demographic characteristics of the sample are systematically changing over time and whose effects we incorrectly attribute to the introduction of the compact. To examine how worker characteristics change in relation to the start of the compact, we also estimate (3) using various control variables as outcomes (but excluding control variables on the right hand side). As a parsimonious way of examining changes in worker characteristics, we construct an index of workers' propensity to participate in the labor force based on observed characteristics and estimate (3) with this index as the outcome. This index was constructed by estimating (via a Probit model) the relationship between labor force participation and our full set of 
control variables in the 1990 Census, then predicting out of sample to all subsequent years.

\section{Border County Analysis}

Since Compact states likely include many individuals that are minimally affected by the Compact because they do not live close to another Compact state, our second approach focuses specifically on residents of the 189 border counties identified in the data. We estimate equations (1) and (2) at the county-level, $c$, instead of the state-level, s. Specifically, we construct our treatment variable, Treatment $_{c t}$, for each county in each year. This variable equals one if county $c$ is in a Compact state and borders at least one other compact state in year t. We then compare changes in outcomes of nurses between border counties that experienced this treatment with those that did not during the same time period. In addition, we include county fixed effects to control for average differences in commuting and employment prevalence across counties that may be related to the adoption of the NLC by the own or bordering state. Figure 5 depicts our border county strategy graphically. Border counties are categorized by whether they are in a Compact state and whether they border another Compact state in 2000 and 2012. Treatment counties are marked in black - they are both in a state that is part of the Compact and border another state that is also part of the Compact. The experience of these counties over time is compared to all other border counties, including those in the same state that happen not to border another Compact state (dark grey) and those in non-Compact states (light grey).

\section{Hosptial-level Analysis}

To get a better sense of more aggregated labor supply effects of the NLC, we examine hospital-level data to see how the number of nurses, among other outcomes, changes after the state in which the hospital resides joins the Compact. If the Compact encourages labor force particpation, we would expect the number of nurses to rise after a hospital's state joins the Compact. Similarly, if the Compact encourages nurses to move to Compact states, we would also expect the number of nurses to rise after a hospital's state joins the Compact. We implement this analysis by estimating (1) and (3) on hospital-level data. We examine the following labor supply outcomes: log number of RNs, log number of LPNs, log number of total nurses (RNs + LPNs), and nurses per hospital admission. 


\section{Threats to Identification}

Since occupational licensing regimes are not experimentally assigned, there are several possible threats to identification that confound estimates of the effect of NLC participation. First, it is possible that other policies are adopted simultaneously with the NLC that only impact nurse labor markets (but not other health workers). We are not aware of any such policies, but cannot rule this out entirely. We think this type of bias is unlikely to affect our border county analysis since treatment depends on the actions of multiple states. Second, our approach takes residency location decisions as exogenous. If the NLC also impacts where nurses choose to live, our estimates may confound true causal effects with changes in the composition of nurses who work in compact states. We explore the robustness of our results to including or excluding observed worker attributes such as education, sex, age, nativity, and family structure and also specifically examine trends in these characteristics leading up to and following states' adoption of the Compact. Finally, we take workers' occupational classification as given, ignoring movements between nursing and other occupations. If the NLC actually alters who enters or remains in nursing (vs. other occupations), then this could create selection bias of unknown direction. Our labor supply results should be interpreted as conditional on chosing to become or remain a nurse.

\section{Results}

\section{A. State-level analysis}

Tables 2 and 3 present our main results for the full sample and each of our labor supply and commuting outcomes. Specifically, Table 2 shows the results using the binary Compact treatment variable and Table 3 displays the results using the continuous measure of treatment. All specifications include year fixed effects, state fixed effects, and the full set of demographic and background controls. The first column for each outcome presents difference-in-difference estimates on the sample of nurses, as described by equation (1). ${ }^{10}$ These difference-in-difference estimates imply that NLC adoption is actually associated with lower levels of labor force participation, employment, labor supply, and lower wage income among nurses (though the estimates are insignificant). The inclusion of demographic cotnrols has little impact on diff-in-diff point estimates (not reported), suggesting that worker composition does not change dramatically

${ }^{10}$ The full set of estimates, including the controls, is reported in the Appendix Table A5. Many relationships are as expected: nurses that are more educated have higher labor force attachment and earnings; nurses with young children or larger families work fewer hours. 
when the NLC is adopted. We only report estimates with controls included, as these are more precise. ${ }^{11}$ In columns (9), (11), and (13) we find that cross-state employment and commute time (among the employed) also has minimal association with the adoption of the Compact.

These basic difference-in-difference estimates are biased if nurses are subject to other policy or labor market shocks or trends that coincide with NLC adoption, such as states adopting the NLC in response to a declining supply of health workers or demand for health services. In this case, states that do not join the NLC would be an inappropriate control for the states that do. The second column for each outcome presents triple difference estimates (equation 2), explicitly using non-nurse health workers as a control group that should be unaffected by NLC adoption. As such, we believe this is a superior form of identification to the basic difference-in-difference model and will be the specifcation that we focus on going forward. In these specifications the parameter of interest is the the interaction between living in a compact state and being a nurse. Estimates are reduced towards zero and tend to be insignficant for almost all outcomes.

Triple difference point estimates suggest that labor force participation, employment, hours worked, or wage income of nurses are unaffected (relative to non-nurse health workers) by the adoption of the NLC. Estimates are sufficiantly precise that we can rule out small positive effects on labor force participation (95\% CI $=-0.006$ to 0.006$)$, employment ( -0.008 to 0.008 ), and hours worked (-0.22 to 1.04). Estimated effects on cross-state employment are positive but small and imprecise, though we do find nurses spend approximately 3.6\% more time commuting to work (significant at the 1\% level) than other health workers when the NLC is adopted.

Table 3 presents displays the effects of the NLC on the outcomes of interest using the continuous measure of treatment described in section 3C. This is our preferred measure of treatment as the simple binary indicator fails to account for the dynamics of policy change or that the effectiveness of the Compact depends on how many other states belong. In general, the results are qualitatively similar, but the magnitudes are much larger because they are scaled by the inverse of the fraction of states that have adopted. The binary Compact treatment provides the effect for a typical state given states' actual participation level in the Compact during our analysis period. The

${ }^{11}$ State and year fixed effects do have a material impact on estimates, suggesting that states adopting the NLC have different labor market characteristics than those that do not and that participation and labor supply are trending over time. Inclusion of demographic controls has little impact on diff-in-diff point estimates (but does improve precision), suggesting that worker composition does not change dramatically when the NLC is adopted. 
continuous treatment, in contrast, provides the effect of joining the Compact conditional on all other states having already joined. Despite the larger coefficients, our insignificant point estimates on labor force participation (95\% CI $=-0.016$ to 0.011 ) and employment (95\% CI $=-0.025$ to 0.013) are still precise enough that we can likely reject any meaningful impact of treatment. Imprecision however, does not rule out positive effects on hours worked, wage, and cross-state employment. The triple difference point estimate suggests that nurses spend approximately $11.2 \%$ more time commuting to work (significant at the 5\% level) than other health workers after "treatment," but this result does not hold in our analysis of border counties (discussed below) so we are cautious of pushing this finding too far.

Table 4 reports results for cross-state migration. Here treatment is defined as in the analysis for labor supply outcomes, but instead we use the share of each states' out-migrants to each other state to construct weights. Unforutnately the Census and ACS collect migration outcomes that are not comparable, so we are restricted to only examine the ACS for our migration analysis. ${ }^{12}$ For the typical nurse, we find no effect of NLC exposure on the likelihood of moving to another state within a year. However, the extremeley low rates of migration make it difficult to detect effects. The next two specifications restrict analysis to the health workers that are in the top quintile of predicted likelihood of moving states, as predicted by baseline demographic characteristics. Young individuals with no children are the most likely to move across state lines. For these individuals, NLC adoption is associated with a 1.5 percentage point increase in the likelihood of moving to any state and 1.0 percentage point increase in the likelihood of moving to a compact state, a sizable increase relative to a base of 5.7 and $2.1 \%$, respectively. ${ }^{13}$ However, these estimates are imprecise and not significantly different from zero. Furthermore, triple difference estimates using non-nurse health workers as an additional control group suggest much weaker effects, particularly for the likelihood of moving to any other state.

Columns (5)-(8) of Table 4 present the cross-state migration results when the full sample is stratified for nurses and health workers who are in "low wage" states and "high wage" states. We define low wage and high wage states using data from the Bureau of Labor Statistics' Occupational Employment and Wage Estimates. States in the highest $50^{\text {th }}$ percentile of wages for RNs and LPNs are defined as "high wage" states and states in the lowest $50^{\text {th }}$ percentile of wages

\footnotetext{
12 The Census collects 5-year migration information but the ACS collects 1-year migration information.

13 The outcome mean for "moved to Compact state" is taken across the entire sample, which includes early years when few states are part of the Compact.
} 
are defined as "low wage" states. ${ }^{14}$ We stratify the data accordingly because it is plausible that the migration decisions of nurses currently living in a low wage state may be particilarly sensitive to NLC adoption as it potentially opens more high wage opportunties. Similar to our other results, however, both the difference-in-difference and triple-difference results are insiginficant, nor do they substantially differ across low wage and high wage states. If anything, the results indicate that the migration of nurses in high-wage states is more responsive to the NLC than nurses in low-wage states. This pattern is inconsistent with the NLC improving flows of nurses from low- to high-wage states, which presumably have greater demand for nurses.

We also address the possibility that workers in urban areas may have different commuting and labor supply patterns than workers in rural areas. To examine this, we estimate equations (1) and (2) but stratify by nurses and health workers living in an MSA and those who are not assigned to an MSA. These results are presented in Appendix Table A2. For the triple difference results, the only statistically significant treatment effect is on comuting time for those living in MSAs.

\section{B. Event-Study Analysis}

The key assumption of the difference-in-difference approaches above is that the treatment counties and states would have followed similar trends as non-treatment counties/states in the absence of exposure to the NLC. While inherently not testable, this assumption is more plausable in cases where outcomes and sample characteristics are trending similarly for treated and non-treated groups in the years leading up to NLC adoption.

Figure 6 presents event-study estimates of NLC introduction on the characteristics of nurses. As a parsimonious way of combining many covariates, we construct an index which captures individuals' propensity to participate in the labor force. This index was constructed by estimating (via a Probit model) the relationship between labor force participation and our set of control variables in the 1990 Census sample, then predicting out of sample to the other years. ${ }^{15}$ As measured by this index, there is no obvious change in nurse characteristics leading up to and following the adoption of the NLC by states. Some individual characteristics do experience modest changes, but taken together these have no systematic pattern with labor force participation.

\footnotetext{
${ }^{14}$ Dividing the wage data into quartiles and examining changes over time indicates that states very rarely change quartiles throughout the sample period. Therefore, we treat the characteristic of being a high wage and low wage state as constant over time.

${ }^{15}$ Estimates from the first stage model are reported in Appendix Table A4.
} 
This echoes our earlier finding that controlling for observed characteristics of nurses has minimal impact on estimates of the effect of the NLC.

Figures 7 and 8 present event-study estimates for our labor supply and commuting outcomes, respectively. Neither labor force participation, employment, or hours worked are systemically trending in Compact states relative to non-Compact states in the years leading up to NLC adoption. Some of these outcomes trend dowward following NLC adoption, consistent with the difference-in-difference estimates. Figure 8 depicts event-study estimates for our commuting outcomes. Again, we see no evidence suggesting pre-trends may bias our difference-in-difference estimates nor is there any evidence that NLC adoption is associated with changes in commuting patterns.

\section{Border County Analysis}

One limitation of the state-level analysis presented in Tables 2 and 3 is that the benefits of the NLC likely acrue to only a modest share of nurses in each Compact state. Many may not have opportunities to work in another Compact state, either because of prohibative distance or because the nearest state is not part of the Compact. In order to focus on nurses most likely to be affected by participation in the Compact, we estimate difference-in-difference and triple difference models exclusively on residents of the 189 border counties identified in our data. Our main explanatory variable is now an indicator for whether the indiviudal resides in a Compact state and borders at least one other state that is also a Compact member. Thus variation in treatment arises both because indivudals’ own state joins the NLC and bordering states do.

Table 5 reports border county estimates for labor supply and commuting outcomes. Even for nurses for whom the NLC expands the geographic reach of their credential the most, we see no increase in labor supply, measured by labor force participation, employment, or hours worked. In fact, point estimates for these outcomes are all negative (and insignificant). Triple difference models, using non-nurse health workers as a within-Compact control group, yield similarly null results. Precision is such that for the triple difference estimates, we can rule out small postive effects for labor force participation (95\% CI = -0.017 to 0.009), employment (-0.022 to 0.004), hours worked (-0.472 to 0.551), wage/salary income (-0.096 to 0.020), and likelihood of working in a different compact state (-0.0156 to 0.0016) Estimated effects on cross-state employment and commute time are insignificant in the triple difference model, though imprecision prevents us from 
ruling out modest postive effects.

Table 6 explores the robustness of the border county triple-difference estimates to alternative specifications and controls. Column (1) repeats our base triple-difference model, which includes county and year fixed effects and full controls. In specification (2) we demonstrate that the inclusion of an exensive vector of observed characteristics have virtually no impact on our point estimates. The characteristics are quite predictive of each outcome (e.g. the R-squared improves from 0.01 to 0.12 when controls are included in the model for hours worked), but do not alter the estimated relationship between treatment and outcomes. The implication is that NLC implementation is uncorrelated with observed changes in nurse charactersitcs.

Our base specification uses the experience of all border counties to form the counterfactual time path for counties exposed to the NLC treatment. The next three columns relax this feature and use the experience of counties that are arguably more similar to treated counties to contruct counterfactuals. In (3) we include state-specific year fixed effects, which implicitly compares treated border counties to border counties in the same state that happen to not border another Compact state. For example, counties along South Carolina's border with North Carolina (a Compact state) are compared to those along its southern border with Georgia (not a Compact state). Similar comparisons can be made in Arizona, Arkansas, Colorado, Iowa, Maryland, Mississippi, Nebraska, New Hampshire, Tennessee, and Texas. Specifications (4) and (5) restrict analysis to only states that had ever joined the NLC and only to treated counties, respectively. In these specifications time trends are estimated from counties that are part of states that have chosen to join the NLC, so should experience a similar policy environment. Specification (6) clusters our standard errors at the county level rather than state level. With a few exceptions, the (mostly null) results from the base model are quite robust to these alternative ways of contructing the counterfactuals. We find no obvious evidence that exposure to the NLC expanded nurse labor supply on the extensive margin. The only evidence we find on the intensive margin is for specifications that focus on NLC states and treated counties. In these specifications, we do find that hours worked increased 0.87 or 1.69 hours (signficiant at the $1 \%$ level), which correspond to a $2.5 \%$ or $4.8 \%$ increase over the mean, respectively. We also find that the wage of nurses in treated counties increases by about $10 \%$ (singificant at the $1 \%$ level).

Interestingly, the coefficeint for works in a different compact state remains negative and remarkably similar to the base specification throughout. While we do not think that the NLC 
actually reduces the likelihood of working in a Compact state for border counties, we interpret this as pretty strong evidence that the NLC did not increase it.

\section{Hospital-level Analysis}

Other than the migration analysis of Table 4, our previous analysis with individual microdata estimates labor supply effects conditional on nurses’ choice of where to live. Shifts in the allocation of nurses across states could generate aggregate changes in the nurse workforce that are not picked up by this micro analysis. To get a more complete picture of the labor supply effects of the NLC, we extend our analysis and examine workforce changes before and after the Compact at the hospital-level using data from the AHA's Annual Survey. Results from estimating equation (1) are presented in Table 7. Panel A displays the results for changes in the log number of full-time equivalent LPNs, RNs, and Total Nurses (RNs + LPNs). The first column of each outcome simply uses an indicator whether the hospital's state is a member of the Compact as the treatment variale, whereas the second column uses the fraction of other states that are part of the compact, weighted by the share of workers the state receives from each sending state, as the treatment. The results are qualitatively similar to those seen using the ACS dataset as every coefficient on both the binary indicator and the continuous treatment are insiginficant indicating little effect of the NLC on the aggregate quantity of nurses employed by hospitals.

From a quality of care perspective, total RNs, LPNs, and overall total nurses may not be the appropriate outcome of interest. While it may seem undesirable to not see an increase in number of nurses, or perhaps even a decrease, following Compact adoption, this has less of an impact on patient care if admissions do not change or decrease. As a result, we also examine changes in the number of LPNs, RNs, and Total Nurses per admission and display the results in columns (1)-(6) in Panel B of Table 7. Again, none of the coefficients on the treatment variables are significant.

Figures 9 and 10 present event-study estimates for the same outcomes examined in Table 7. Treatment in these figures is whether the state in which the hospital is located is part of the Compact. In Figure 9, the coefficient on log full-time equivalent RNs is positive and becomes marginally significant (10\% level) for years 2 and 3 post-compact introduction, but is small in magnitude (less than 2\%). The same is true for year 2 when examining total nurses. In Figure 10, we see no discernable effect of the Compact on the ratio of Nurses per Admission in the years following the introduction of the Compact. For neither set of outcomes do we see any evidence 
that employment of hospital-based nurses is trending prior to the enactment of the Compact, giving us confidence that our AHA difference-in-difference estimates are not biased by pre-treatment differences between treatment and control states.

\section{Conclusion}

The Nurse Licensure Compact (NLC) was first introduced in 2000 and allows Registered Nurses and Licensed Practical Nurses with licenses in one NLC-member state to practice in other NLC states without obtaining a separate license. The Compact was created with the intention of providing greater mobility for nurses, clarifying the authority to practice for nurses currently engaged in telenursing or interstate practice, improving access to nursing care in general and during a disaster or other times of great need, and enhancing information-sharing among member NLC states. While only four states joined the Compact in its first year, currently 25 states are now members and a few more have pending legislation. Furthermore, the NLC has been promoted as a model for other occupations to follow (U.S. Department of the Treasury, 2015). In fact, the Interstate Medical Licensure Compact was recently adopted by nine states to address the same set of issues for physicians, albeit with some important procedural differencess from the NLC (Chaudhry et. al, 2015).

In this paper, we estimate the effects of the Compact on labor force, migration, and commuting outcomes. In comparison to other health workers who were not affected by the Compact, we find little evidence that the labor supply or mobility of nurses increased following the adoption of the Compact in the nurses' home state. Specifically, we find no effect on labor force particpation, employment levels, hours worked, wages or the probability of working across state lines. When limiting our sample to nurses that live in border counties and examining the effect of living in a Compact state and bordering another member state, we similarly find no effect on labor market outcomes, including commuting times, for most specifications. Effects on cross-state migration are imprecise, but leave open the possibility that the NLC impacts cross-state migration for very mobile workers. Supplemental hospital-level analysis also revealed no measureable impact of NLC exposure on the aggregate nurse hours worked at hospitals.

While this is the first study to empirically look at the inter-state licensing, we recognize that it is only a first step towards fully identifying its consequences. Our measures are not rich enough to capture the diverse work arrangements enabled by the NLC, including telnursing or 
working in multiple states simultaneously. To get a fuller picture of the effect of the NLC, it is necessary to test whether access to care increased following the adoption of the Compact in a patient's home state, and how this has affected the prevalence and scope of telenursing throughout the United States. Furthermore, it is possible that the benefits of a cross-state system of occupational licensing will only acrue if the licensing regime is truly national. Even with the Compact, nurses still face barriers when moving across states or working in non-Compact states. Although the requirements of licensing and "licensing by endorsement" vary across states, they do not vary substantially. Application fees and waiting periods for temporary licenses top off around $\$ 250$ and 6 weeks, respectively (U.S. Department of the Treasury, U.S. Department of Defense, 2012). While these amounts are non-trivial, they may not be large enough that the elimination of these barriers will yield measureable effects on mobility. Furthermore, nurses that move between NLC states will still have to pay the application fee to obtain a new license, though they are permitted to work immediately. Though the NLC provides the best evidence to date on the likely effects of a nationalized licensing system, it still may not go far enough to generate measurable impacts on the nurse labor market.

While we do not find that the multistate licensing provided by the NLC reduces labor market frictions caused by occupational licensing, it is important to note that we necessarily focus on nurses. The results may not generalize to other licensed professionals, such as lawyers, therapists, physicians and teachers. From a healthcare delivery perspective, our results indicate that the NLC is likely not to increase the labor supply of nurses. We find no evidence that reducing licensing barriers will increase the pool of workers from which hospitals draw or that it will bring nurses into the labor force. As a result, this reduction in licensing barriers does not appear to be a solution to an aggregate shortage of nurses. 


\section{References}

Angrist, J. D., and Guryan, J. (2008). Does teacher testing raise teacher quality? Evidence from state certification requirements. Economics of Education Review, 27(5), 483-503.

Barnum, B. (1997). Licensure, Certification, and Accreditation, Online Journal of Issues in Nursing, 2(3).

Benefiel, D. (2011). The Story of Nurse Licensure, Nurse Educator, 36(1), 16-20.

Blanchard, O. and L.F. Katz. (1992). "Regional Evolutions,” Brookings Papers on Economic Activity 1, Vol. 3, pp. 1-77.

Bryson, A., and Kleiner, M. M. (2010). The Regulation of Occupations. British Journal of Industrial Relations, 48(4), 670-675.

Buerhaus, P.I., Auerbach, D.I., and Staiger, D.O. (2009). The recent surge in nurse employment: causes and implications. Health Affairs, 28(4), w657-w668.

Chaudhry, Humayun J., Lisa A. Robin, Eric M. Fish, Donald H. Polk, and J. Daniel Gifford. 2015. "Improving Access and Mobility - The Interstate Medical Licensure Compact." The New England Journal of Medicine 372, no. 17: 1581-1583.

Dao, M., D. Furceri, and P. Loungani. (2014). "Regional Labor Market Adjustments in the United States.” IMF Working Paper No 14-211. (November 2014).

Holen, A. S. (2012). Effects of Professional Licensing Arrangements on Interstate Labor Mobility and Resource Allocation. Journal of Political Economy, 73(5), 492-498

Hotz, V. J., and Xiao, M. (2009). The Impact of Regulations on the Supply and Quality of Care in Child Care Markets, Working paper, (pp. 1-52).

Kleiner, M. M., (2000). Occupational Licensing. Journal of Economic Perspectives 14, 189-202.

Kleiner, M.M., (2006) Licensing Occupations: Ensuring Quality or Restricting Competition? Kalamazoo, Mich.: W. E. Upjohn Institute.

Kleiner, M. M. (2011). Occupational Licensing. The Journal of Economic Perspectives, 14(4), 189-202.

Kleiner, M. M., and Krueger, A. B. (2009). Analyzing the Extent and Influence of Occupational Licensing on the Labor Market. NBER Working Paper (pp. 1-35).

Kleiner, M. M., and Krueger, A. B. (2010). The Prevalence and Effects of Occupational Licensing. British Journal of Industrial Relations, 48(4), 676-687. 
Kleiner, M. M., and Kudrle, R. T. (2000). Does Regulation Affect Economic Outcomes? The Case of Dentistry. Journal of Law and Economics, 43(October), 547-582.

Kleiner, M. M., Gay, R. S., and Greene, K. (1982b). Licensing, Migraton, and Earnings: Some Empirical Insights. Review of Policy Research, 1(3), 510-522.

Kleiner, M. M., Gay, R. S., and Greene, K. (1982a). Barriers to Labor Migration: The Case of Occupational Licensing. Industrial Relations, 21(3), 383-391.

Kleiner, M. M., and Won Park, K. (2010). Battles Among Licensed Occupations: Analyzing Government Regulations on Labor Market Outcomes for Dentists and Hygienists, Working paper, (pp. 1-40).

Kleiner, M. M., Marier, A., Won Park, K., and Wing, C. (2010). Relaxing Occupational Licensing Requirements: Analyzing Wages and Prices for a Medical Service, Working paper.

Kugler, A. D., and Sauer, R. M. (2005). Doctors without Borders? Relicensing Requirements and Negative Selection in the Market for Physicians. Journal of Labor Economics, 23(3), 437-465.

Molloy, R., C.L. Smith, and A. Wozniak. (2011). "Internal Migration in the United States.” Journal of Economic Perspectives, 25(3): 173-196.

Pashigan, B. P. (1979).Occupational Licensing and the Interstate Mobility of Professionals,. Journal of Law and Economics, 22(1), 1-25.

Peterson, B. D., Pandya, S. S., and Leblang, D. (2014). Doctors with borders: occupational licensing as an implicit barrier to high skill migration. Public Choice, January.

Sass, Tim R. (2015). Licensure and Worker Quality: A Comparison of Alternative Routes to Teaching. Journal of Law and Economics, 58 (February): 1-35

Schaumans, C., and Verboven, F. (2008). Entry and regulation: evidence from health care professions. The Rand Journal of Economics, 39(4), 949-72.

Sulentic, A. M. (1999). Crossing Borders?: The Licensure of Interstate. Journal of Legislation, 25(1), 1-37.

Stange, K. (2014). How Does Provider Supply and Regulation Influence Health Care Markets? Evidence from Nurse Practitioners and Physician Assistants. Journal of Health Economics, 33(2014), 1-27.

Thornton, R. J., and Timmons, E. J. (2013). Licensing One of the World s Oldest Professions?: Massage. Journal of Law and Economics, 56(2), 371-388. 
U.S. Department of the Treasury Office of Economic Policy, Council of Economic Advisers, and the Department of Labor. (2015). Occupation Licensing: A Framework for Policymakers. Retrieved May 5, 2016 from

https://www.whitehouse.gov/sites/default/files/docs/licensing_report_final_nonembargo. pdf.

U.S. Department of Treasury and U.S. Department of Defense. (2012). Supporting our Military Families: Best Practices for Streamlining Occupational Licensing Across State Lines. Retrieved May 5, 2016 from http://archive.defense.gov/home/pdf/Occupational_Licensing_and_Military_Spouses_Re port_vFINAL.PDF

Weeden, K. A. (2002). Why Do Some Occupations Pay More than Others? Social Closure and Earnings Inequality in the United States. American Journal of Sociology, 108(1), 55-101.

Zapletal, M. (2014). The Effects of Occupational Licensing: Evidence from Detailed Business-Level Data, Working paper, (pp. 1-54). 
Figure 1. Number of States Participating in NLC, 1995 to 2011

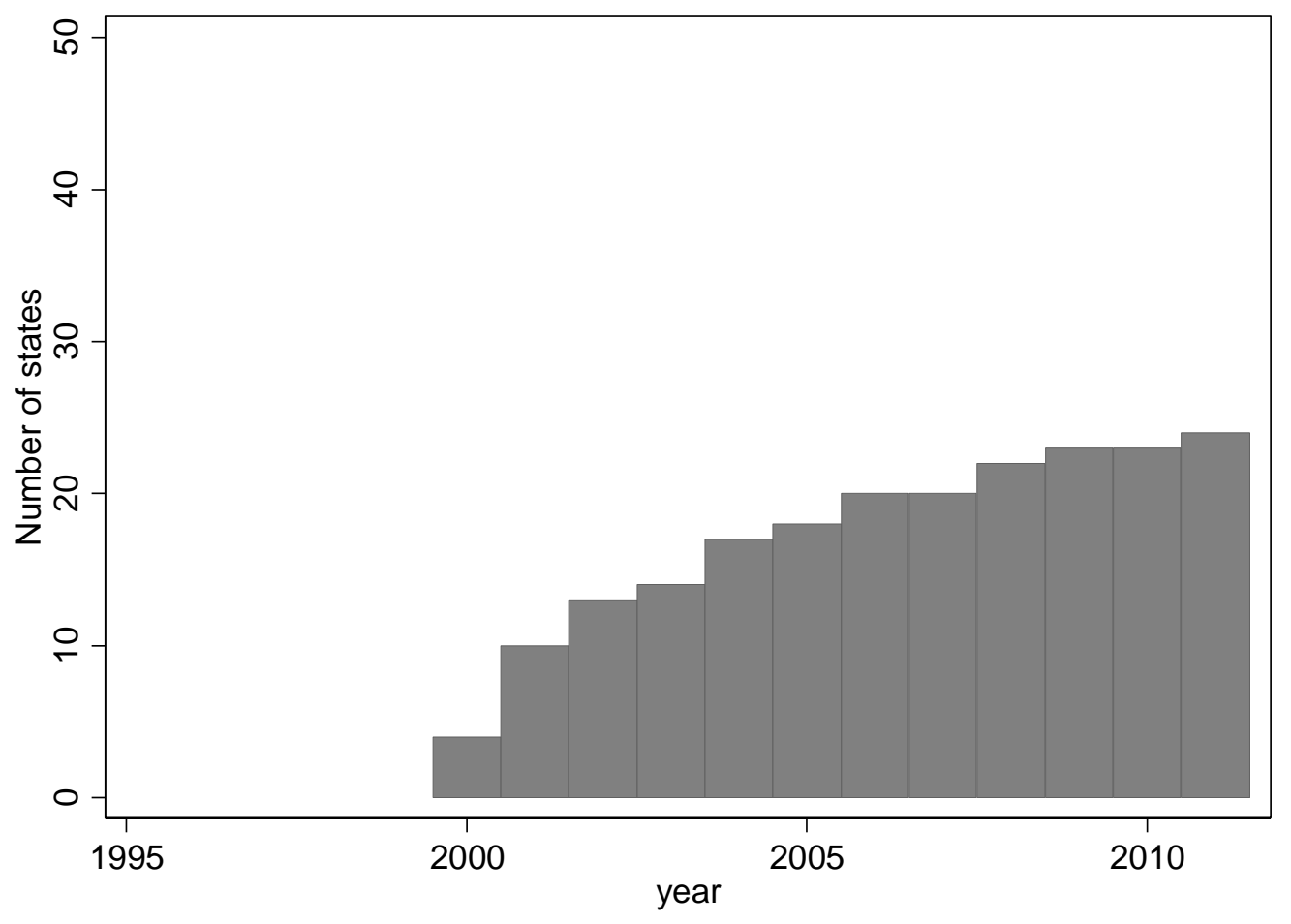

Notes: States are considered to be participating in the NLC during a given year if the implementation date is in February of that year or earlier.

Source: https://www.ncsbn.org/nurse-licensure-compact.htm 
Figure 2. Nurse Licensure Compact States, 2000 and 2012
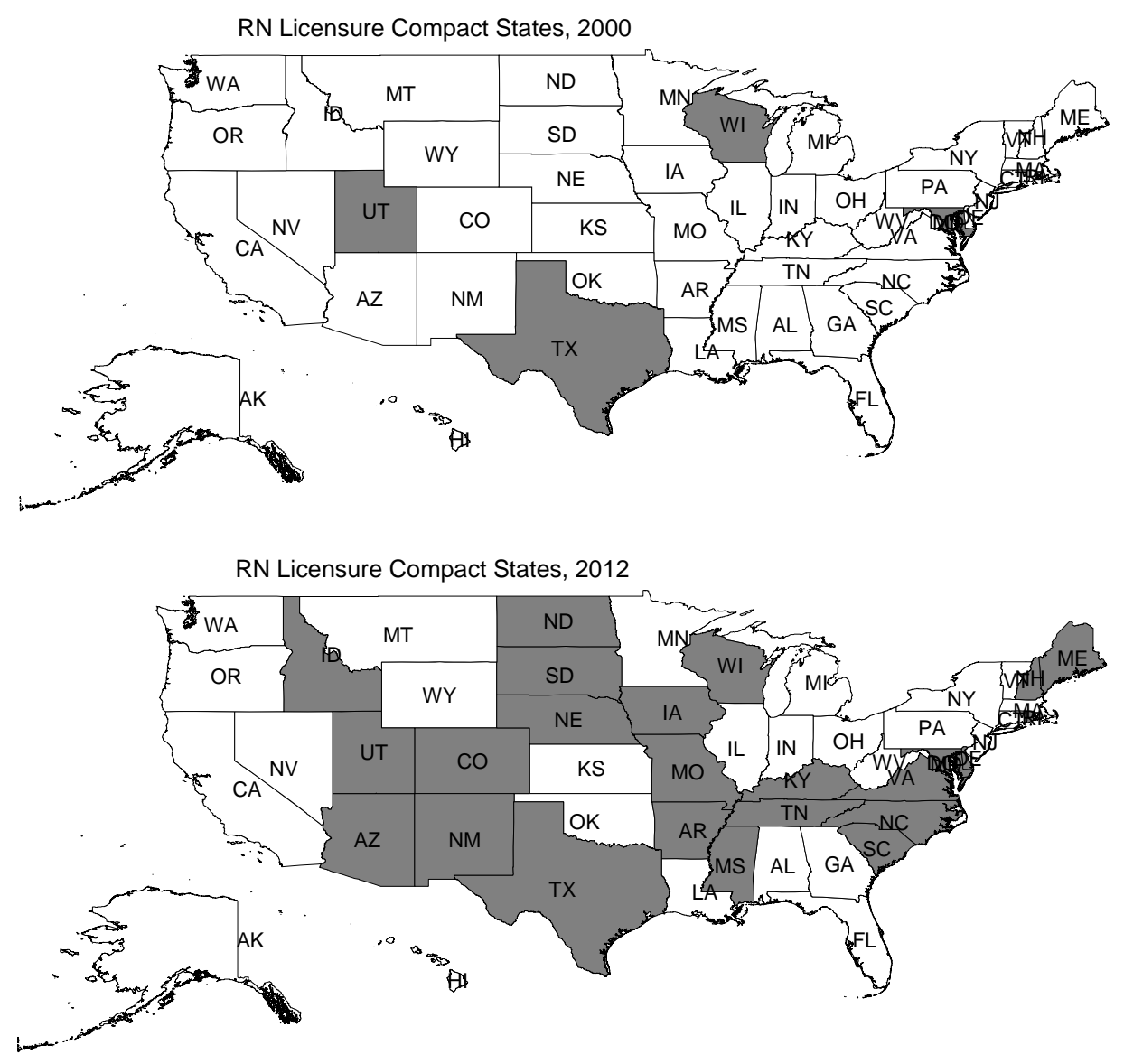

Notes: States are considered to be participating in the NLC during a given year if the implementation date is in February of that year or earlier.

Source: https://www.ncsbn.org/nurse-licensure-compact.htm 
Figure 3. Flow Chart for Obtaining Nurse License

Navigating the Nurse Licensure Compact:

NURSE LICENSURE COMPACT

Initial Licensure by Examination for New Graduates

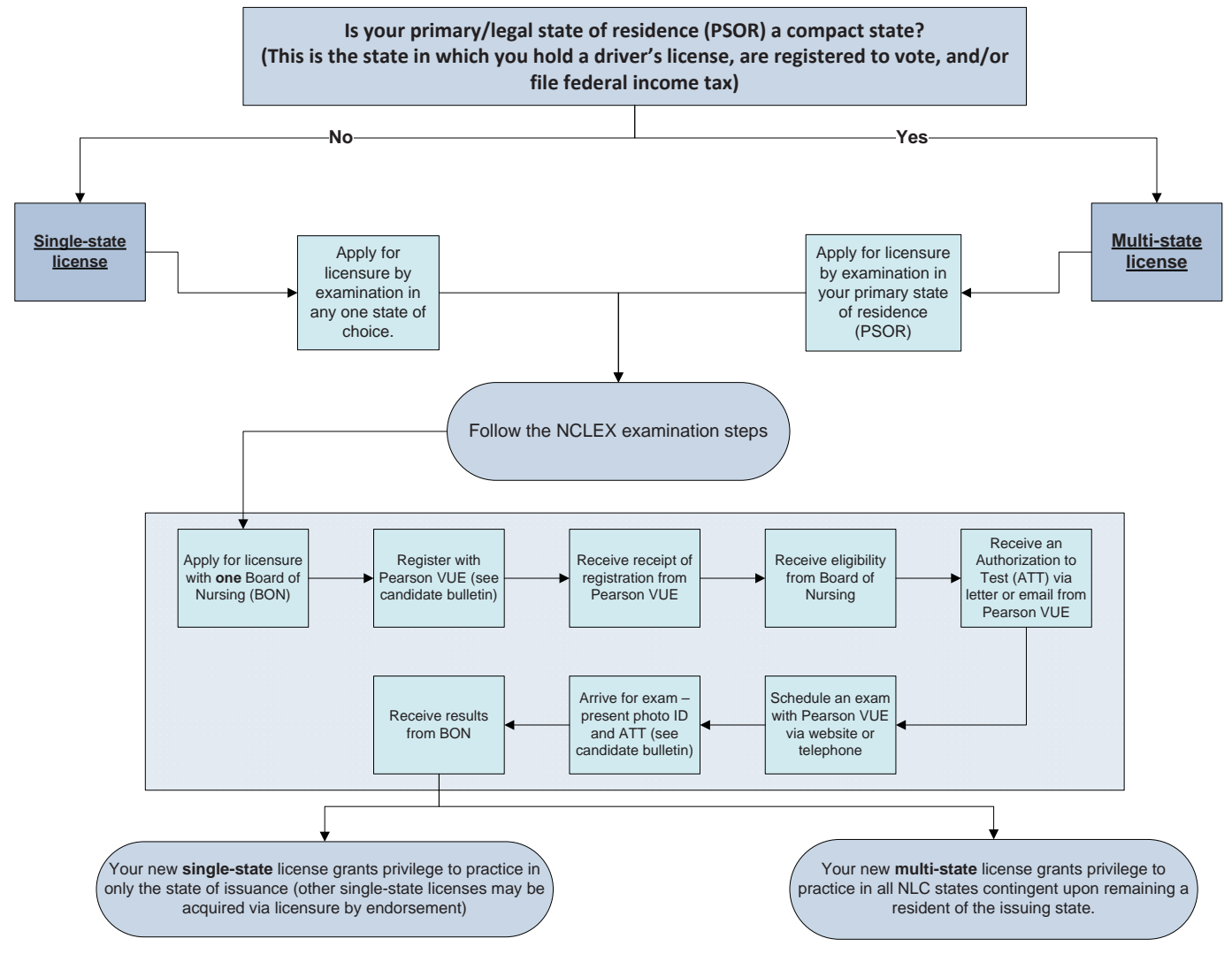

Source: https://www.ncsbn.org/nurse-licensure-compact.htm 
Figure 4. Continuous Treatment for Six States
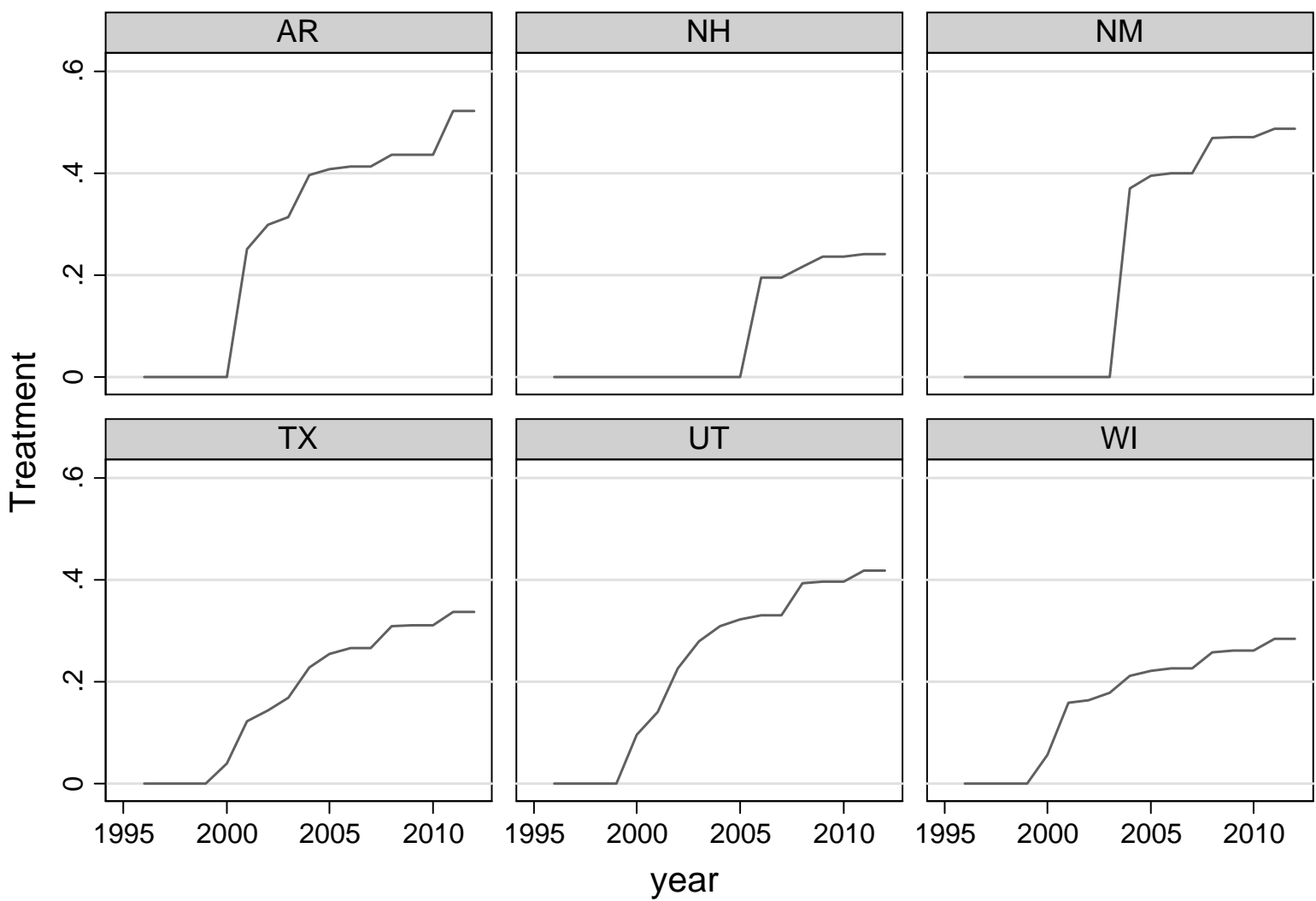

Notes: Graphs plot, separately for six states, the fraction of other states that are part of the Compact, weighted by the share of workers each reported state receives from each sending state. If a state is not part of the compact, then the treatment is equal to zero. Weights are estimated using the 1990 and 2000 decennial census and represent five-year migration rates. 
Figure 5. Border Counties Exposed to Compact
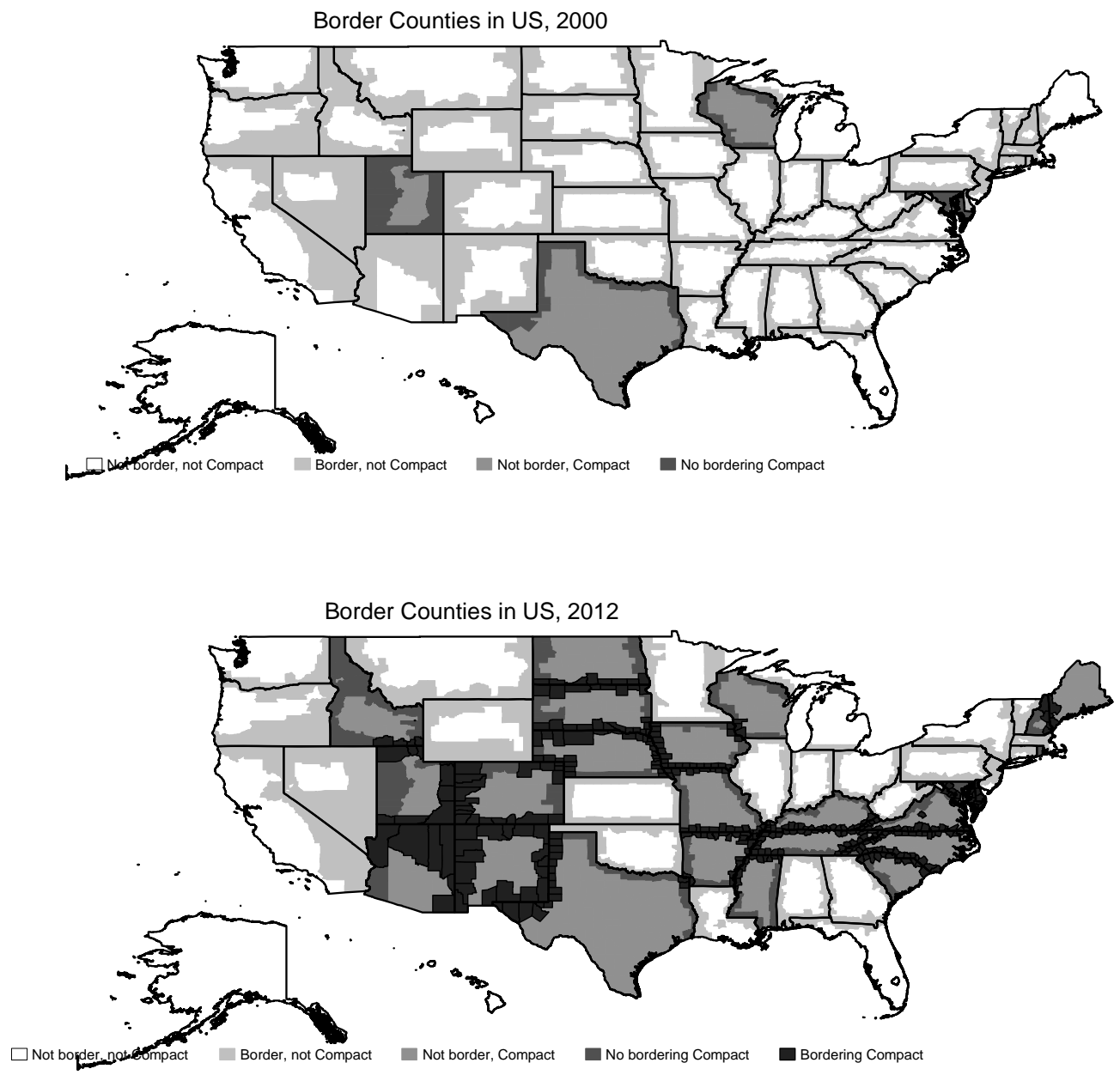
Figure 6. Changes in Worker Characteristics Leading up to and Following NLC Adoption

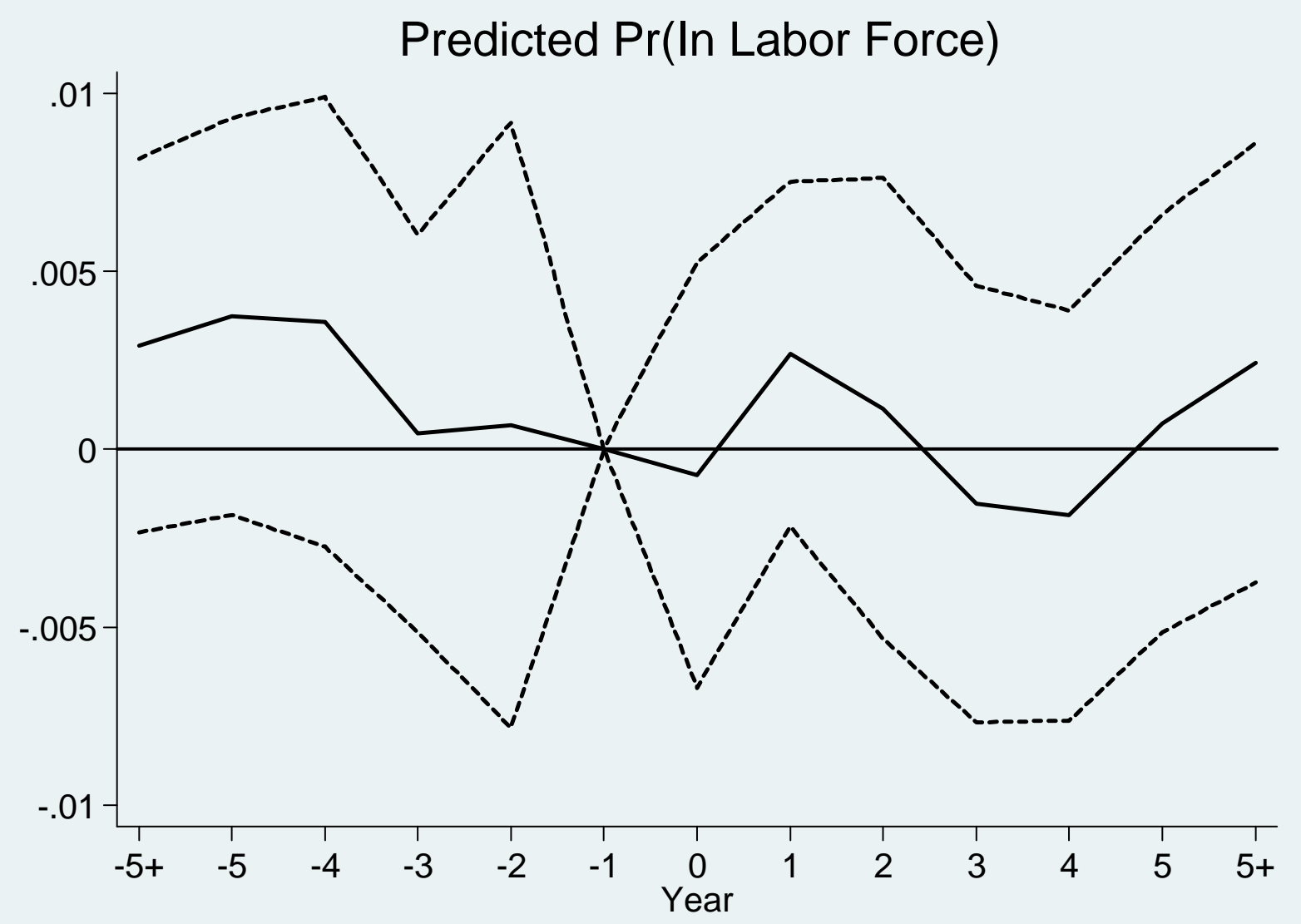

Notes: Outcome is labor force participation as predicted with covariates from a two-step approach. First, labor force participation is regressed on covariates using the 1990 Census. Second, model estimates are then used to predict labor force participation based on the same covariates, but in all years. Figure plots coefficients on indicators for time until or since NLC adoption. Model includes state and year fixed effects. Dashed lines represent $95 \%$ confidence interval. Standard errors clustered by state. 
Figure 7. Changes in Labor Supply Leading up to and Following NLC Adoption (Nurses only with Controls)
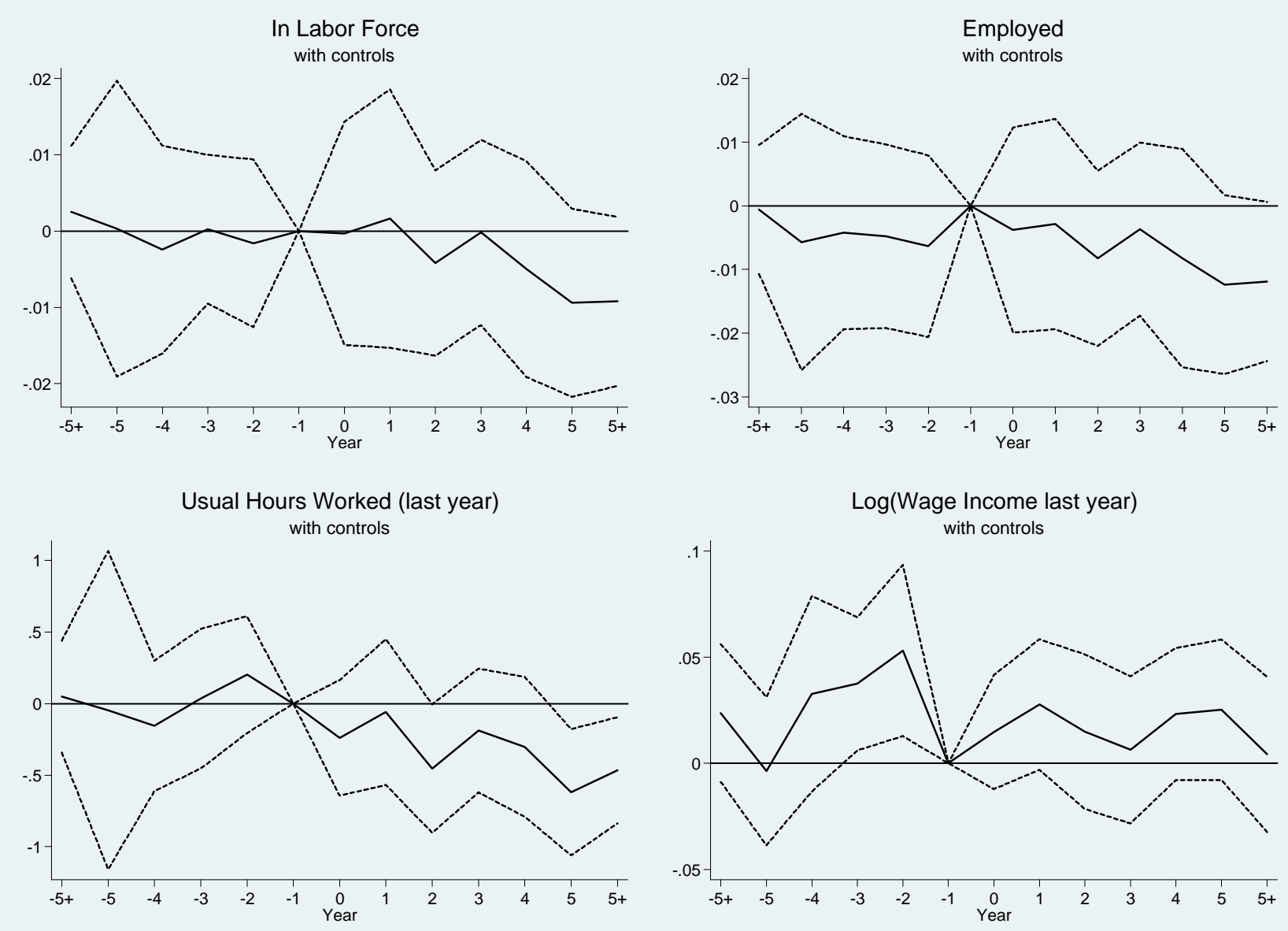

Notes: Figure plots coefficients on indicators for time until or since NLC adoption. Model includes state and year fixed effects and a full set of control variables. Dashed lines represent $95 \%$ confidence interval. Standard errors clustered by state. Coefficients normalized to zero in the year before adoption. Year zero is first year of adoption. 
Figure 8. Changes in Commuting Outcomes Leading up to and Following NLC Adoption (Nurses only with Controls)
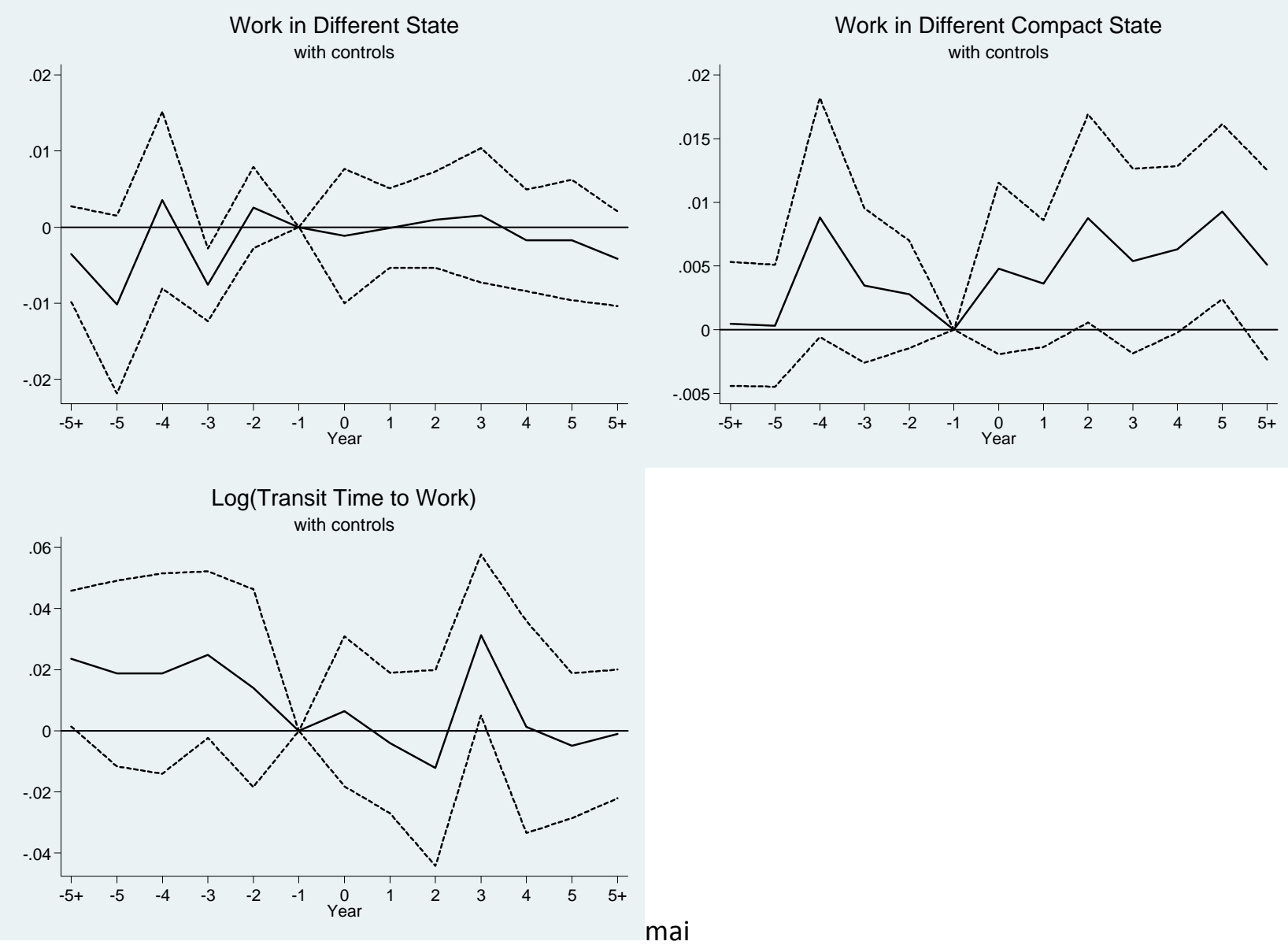

Notes: Figure plots coefficients on indicators for time until or since NLC adoption. Model includes state and year fixed effects and a full set of control variables. Dashed lines represent $95 \%$ confidence interval.

Standard errors clustered by state. Coefficients normalized to zero in the year before adoption. Year zero is first year of adoption. 
Figure 9. Changes in Aggregate Hospital Nurse Hours Leading up to and Following NLC Adoption
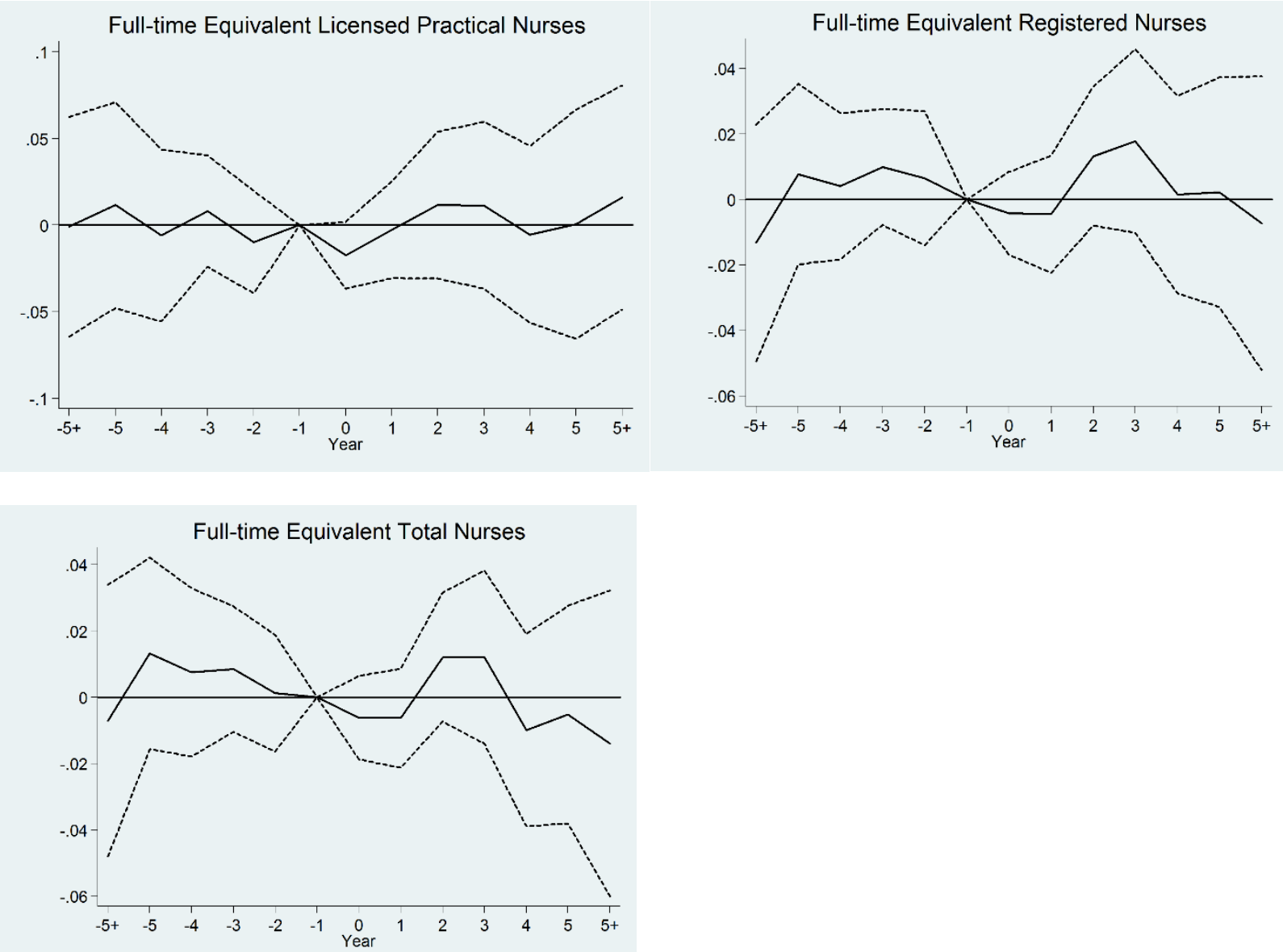

Notes: Figure plots coefficients on interaction between time until or since NLC adoption. Model includes hospital and year fixed effects and a full set of control variables. The y-axis for LPNs, RNs, and Total Nurses are log points. Dashed lines represent 95\% confidence interval. Standard errors clustered by state. Year zero is first year of adoption. Sample includes all hospitals in the US in the AHA, 1995-2009. 
Figure 10. Changes in Labor Supply per admission leading up to and Following NLC Adoption
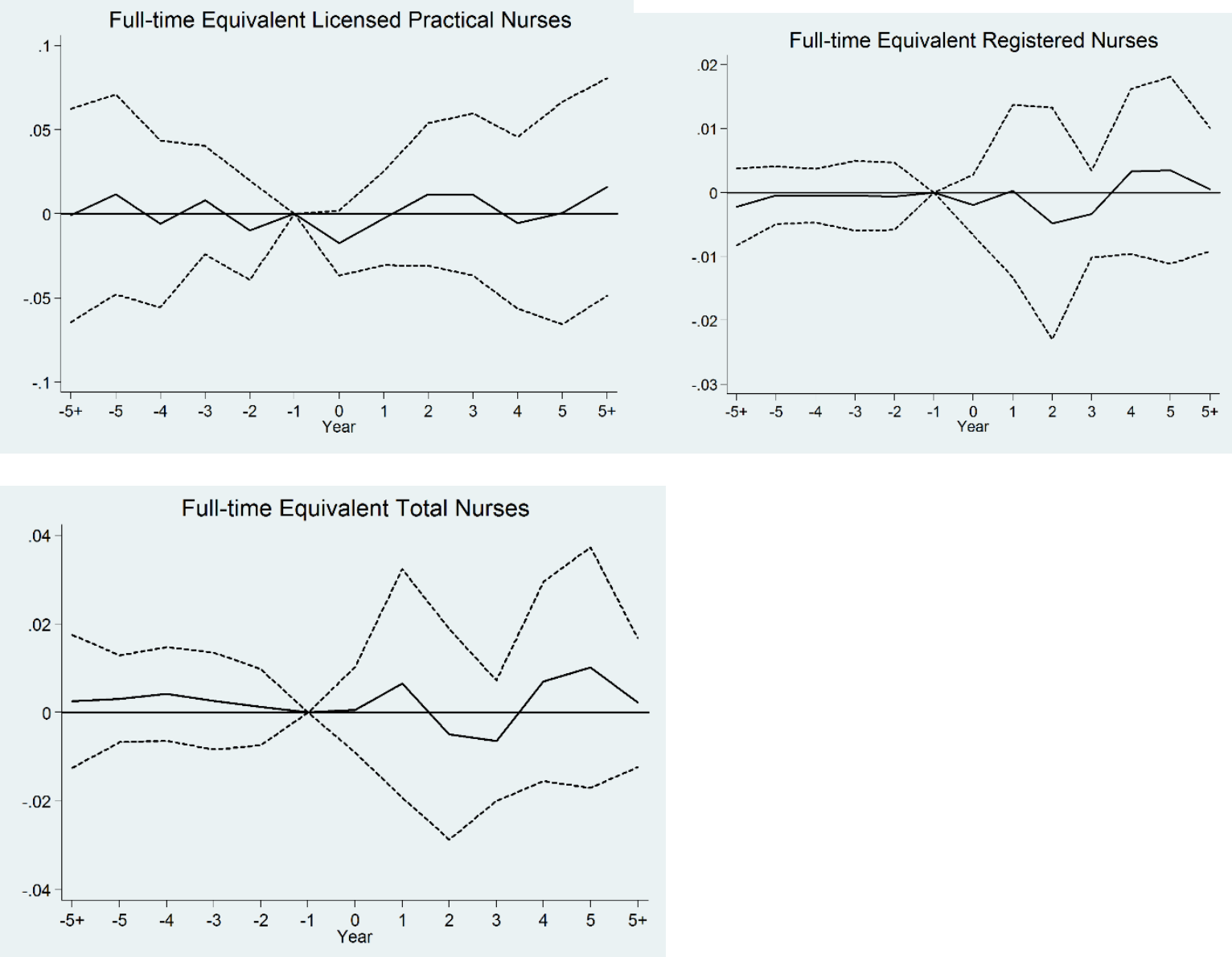

Notes: Figure plots coefficients on interaction between time until or since NLC adoption. Model includes hospital and year fixed effects and a full set of control variables. The $y$-axis for Nurse per Doctor is measured in levels. Dashed lines represent $95 \%$ confidence interval. Standard errors clustered by state. Year zero is first year of adoption. Sample includes all hospitals in the US in the AHA, 1995-2009. 


\begin{tabular}{|c|c|c|c|c|c|c|c|c|c|c|c|c|}
\hline & \multicolumn{6}{|c|}{ Nurses only } & \multicolumn{6}{|c|}{ All health workers } \\
\hline & \multicolumn{3}{|c|}{ All counties } & \multicolumn{3}{|c|}{ Border counties only } & \multicolumn{3}{|c|}{ All counties } & \multicolumn{3}{|c|}{ Border counties only } \\
\hline & Full sample & $\begin{array}{l}\text { Currently } \\
\text { part of } \\
\text { Compact }\end{array}$ & $\begin{array}{c}\text { Not } \\
\text { currently in } \\
\text { Compact }\end{array}$ & $\begin{array}{c}\text { Full } \\
\text { sample }\end{array}$ & $\begin{array}{l}\text { State and } \\
\text { border } \\
\text { compact }\end{array}$ & $\begin{array}{c}\text { Not state } \\
\text { and border } \\
\text { compact }\end{array}$ & Full sample & $\begin{array}{l}\text { Currently } \\
\text { part of } \\
\text { Compact }\end{array}$ & $\begin{array}{l}\text { Not currently } \\
\text { in Compact }\end{array}$ & $\begin{array}{c}\text { Full } \\
\text { sample }\end{array}$ & $\begin{array}{c}\text { State and } \\
\text { border } \\
\text { compact }\end{array}$ & $\begin{array}{c}\text { Not state } \\
\text { and border } \\
\text { compact }\end{array}$ \\
\hline In labor force & 0.87 & 0.88 & 0.87 & 0.87 & 0.89 & 0.87 & 0.86 & 0.86 & 0.86 & 0.87 & 0.88 & 0.86 \\
\hline Employed & 0.85 & 0.86 & 0.85 & 0.86 & 0.87 & 0.86 & 0.83 & 0.84 & 0.83 & 0.84 & 0.86 & 0.84 \\
\hline Work in different state & 0.04 & 0.04 & 0.03 & 0.07 & 0.14 & 0.06 & 0.03 & 0.04 & 0.03 & 0.06 & 0.12 & 0.06 \\
\hline Travel time to work & 24.01 & 24.40 & 23.91 & 25.14 & 25.65 & 25.10 & 23.21 & 22.98 & 23.27 & 25.49 & 24.61 & 25.55 \\
\hline Usual hours worked (last year) & 33.84 & 34.36 & 33.70 & 33.73 & 34.62 & 33.66 & 34.31 & 34.21 & 34.34 & 34.54 & 34.72 & 34.52 \\
\hline Wage/salary income, \$1999 (last year) & 32,689 & 32,788 & 32,664 & 35,681 & 35,834 & 35,669 & 31,395 & 29,673 & 31,831 & 34,520 & 33,027 & 34,631 \\
\hline Registered nurse & 0.79 & 0.79 & 0.79 & 0.83 & 0.83 & 0.83 & 0.30 & 0.29 & 0.30 & 0.30 & 0.32 & 0.30 \\
\hline LPN & 0.21 & 0.21 & 0.21 & 0.17 & 0.17 & 0.17 & 0.08 & 0.08 & 0.08 & 0.06 & 0.07 & 0.06 \\
\hline Male & 0.07 & 0.08 & 0.07 & 0.07 & 0.08 & 0.07 & 0.19 & 0.17 & 0.19 & 0.20 & 0.17 & 0.20 \\
\hline White & 0.82 & 0.83 & 0.82 & 0.73 & 0.71 & 0.73 & 0.79 & 0.79 & 0.78 & 0.69 & 0.67 & 0.69 \\
\hline Black & 0.10 & 0.11 & 0.10 & 0.16 & 0.21 & 0.16 & 0.12 & 0.13 & 0.11 & 0.19 & 0.23 & 0.19 \\
\hline American Indian & 0.01 & 0.01 & 0.01 & 0.00 & 0.01 & 0.00 & 0.01 & 0.01 & 0.01 & 0.00 & 0.01 & 0.00 \\
\hline Asian & 0.05 & 0.03 & 0.06 & 0.08 & 0.05 & 0.08 & 0.05 & 0.03 & 0.06 & 0.07 & 0.05 & 0.07 \\
\hline Other & 0.01 & 0.01 & 0.01 & 0.01 & 0.01 & 0.01 & 0.02 & 0.03 & 0.02 & 0.03 & 0.02 & 0.03 \\
\hline Less than high school & 0.01 & 0.00 & 0.01 & 0.01 & 0.00 & 0.01 & 0.04 & 0.04 & 0.04 & 0.04 & 0.03 & 0.04 \\
\hline High school & 0.09 & 0.09 & 0.10 & 0.09 & 0.08 & 0.09 & 0.22 & 0.23 & 0.22 & 0.21 & 0.19 & 0.21 \\
\hline Some college & 0.48 & 0.49 & 0.48 & 0.42 & 0.41 & 0.42 & 0.36 & 0.38 & 0.36 & 0.32 & 0.35 & 0.32 \\
\hline College graduate & 0.31 & 0.33 & 0.31 & 0.35 & 0.39 & 0.35 & 0.21 & 0.21 & 0.21 & 0.23 & 0.26 & 0.23 \\
\hline Graduate degree & 0.11 & 0.09 & 0.11 & 0.13 & 0.12 & 0.13 & 0.17 & 0.14 & 0.18 & 0.20 & 0.18 & 0.20 \\
\hline Age & 44.74 & 45.45 & 44.56 & 44.68 & 45.84 & 44.59 & 42.33 & 42.68 & 42.24 & 42.41 & 43.21 & 42.35 \\
\hline Single household & 0.18 & 0.18 & 0.18 & 0.19 & 0.20 & 0.19 & 0.19 & 0.19 & 0.19 & 0.20 & 0.21 & 0.20 \\
\hline Family size & 2.88 & 2.80 & 2.90 & 2.93 & 2.79 & 2.94 & 2.89 & 2.84 & 2.90 & 2.95 & 2.83 & 2.95 \\
\hline No Child Household & 0.47 & 0.50 & 0.46 & 0.46 & 0.50 & 0.46 & 0.50 & 0.51 & 0.50 & 0.49 & 0.52 & 0.49 \\
\hline One Child Household & 0.22 & 0.21 & 0.22 & 0.22 & 0.22 & 0.22 & 0.21 & 0.21 & 0.21 & 0.21 & 0.21 & 0.21 \\
\hline Two Children Household & 0.20 & 0.19 & 0.21 & 0.21 & 0.18 & 0.21 & 0.19 & 0.18 & 0.19 & 0.19 & 0.18 & 0.19 \\
\hline Few Children Household & 0.10 & 0.10 & 0.10 & 0.11 & 0.09 & 0.11 & 0.10 & 0.09 & 0.10 & 0.10 & 0.09 & 0.10 \\
\hline Many Children Household & 0.01 & 0.01 & 0.01 & 0.01 & 0.00 & 0.01 & 0.01 & 0.01 & 0.01 & 0.01 & 0.01 & 0.01 \\
\hline No Child Under 5 in Household & 0.86 & 0.86 & 0.86 & 0.86 & 0.87 & 0.85 & 0.84 & 0.85 & 0.84 & 0.84 & 0.85 & 0.84 \\
\hline American Citizen & 0.89 & 0.91 & 0.88 & 0.82 & 0.83 & 0.82 & 0.87 & 0.91 & 0.87 & 0.80 & 0.83 & 0.80 \\
\hline Born Abroad & 0.01 & 0.01 & 0.01 & 0.01 & 0.01 & 0.01 & 0.01 & 0.01 & 0.01 & 0.01 & 0.01 & 0.01 \\
\hline Naturalized citizen & 0.07 & 0.05 & 0.07 & 0.11 & 0.10 & 0.11 & 0.07 & 0.05 & 0.08 & 0.12 & 0.10 & 0.12 \\
\hline Not citizen & 0.04 & 0.03 & 0.04 & 0.05 & 0.05 & 0.05 & 0.04 & 0.03 & 0.05 & 0.07 & 0.06 & 0.07 \\
\hline Observations & 680,623 & 136,505 & 544,118 & 127,639 & 9,452 & 118,187 & $1,824,923$ & 300,880 & $1,456,217$ & 348,486 & 24,158 & 324,328 \\
\hline Number of states & 51 & 24 & 51 & 44 & 16 & 43 & 51 & 24 & 51 & 44 & 16 & 43 \\
\hline Number of counties & All & All & All & 189 & 38 & 185 & All & All & All & 189 & 38 & 185 \\
\hline
\end{tabular}


Table 2. Main Results for Full Sample

Binary Treatment

\begin{tabular}{|c|c|c|c|c|c|c|c|c|c|c|c|c|c|c|}
\hline & \multicolumn{2}{|c|}{$\begin{array}{l}\text { In labor force } \\
\text { (current) }\end{array}$} & \multicolumn{2}{|c|}{$\begin{array}{l}\text { Employed } \\
\text { (current) }\end{array}$} & \multicolumn{2}{|c|}{$\begin{array}{l}\text { Usual hours worked } \\
\text { (last year) }\end{array}$} & \multicolumn{2}{|c|}{$\begin{array}{c}\text { Log(Wage income) } \\
\text { (last year) }\end{array}$} & \multicolumn{2}{|c|}{$\begin{array}{l}\text { Work in different } \\
\text { state }\end{array}$} & \multicolumn{2}{|c|}{$\begin{array}{l}\text { Work in different } \\
\text { compact state }\end{array}$} & \multicolumn{2}{|c|}{$\begin{array}{l}\text { Log(Commute time) } \\
\text { (current) }\end{array}$} \\
\hline & (1) & (2) & (3) & (4) & (5) & (6) & (7) & $(8)$ & (9) & $(10)$ & $(11)$ & $(12)$ & (13) & (14) \\
\hline \multirow{2}{*}{ Compact state } & -0.0034 & -0.0034 & -0.0041 & -0.0037 & $-0.3332^{\star \star}$ & $-0.4139^{\star \star}$ & -0.0069 & -0.0148 & 0.0011 & -0.0003 & 0.0039 & 0.0020 & -0.0132 & -0.0104 \\
\hline & $(0.0040)$ & $(0.0027)$ & $(0.0040)$ & $(0.0036)$ & $(0.1335)$ & $(0.1960)$ & $(0.0122)$ & $(0.0143)$ & $(0.0023)$ & $(0.0030)$ & $(0.0024)$ & $(0.0020)$ & $(0.0088)$ & $(0.0079)$ \\
\hline \multirow[t]{2}{*}{ Nurse } & & $0.0247^{\star \star \star}$ & & $0.0338^{\star \star \star}$ & & $0.9091^{\star \star \star}$ & & $0.3468^{\star \star \star}$ & & $0.0059^{\star \star \star}$ & & 0.0007 & & $0.0549^{\star \star \star}$ \\
\hline & & $(0.0016)$ & & $(0.0017)$ & & $(0.0970)$ & & $(0.0139)$ & & $(0.0020)$ & & $(0.0004)$ & & $(0.0093)$ \\
\hline \multirow{2}{*}{ Compact state $\mathrm{X}$ Nurse } & & 0.0003 & & -0.0004 & & 0.4145 & & 0.0263 & & 0.0007 & & 0.0014 & & $0.0357^{\star \star}$ \\
\hline & & $(0.0031)$ & & $(0.0042)$ & & $(0.3151)$ & & $(0.0303)$ & & $(0.0034)$ & & $(0.0012)$ & & $(0.0145)$ \\
\hline Observations & 680,588 & $1,824,791$ & 680,588 & $1,824,791$ & 680,588 & $1,824,791$ & 617,305 & $1,602,769$ & 564,580 & $1,482,355$ & 564,580 & $1,482,355$ & 559,723 & $1,458,395$ \\
\hline R-squared & 0.1282 & 0.0843 & 0.1159 & 0.0788 & 0.1259 & 0.1223 & 0.1557 & 0.2972 & 0.0381 & 0.0333 & 0.0179 & 0.0195 & 0.0295 & 0.0407 \\
\hline Sample & Nurses & All health & Nurses & All health & Nurses & All health & Nurses & All health & Nurses & All health & Nurses & All health & Nurses & All health \\
\hline Outcome mean & 0.884 & 0.871 & 0.867 & 0.842 & 34.41 & 34.40 & 10.30 & 10.02 & 0.035 & 0.030 & 0.008 & 0.008 & 2.97 & 2.93 \\
\hline
\end{tabular}

Notes: All specifications include state fixed effects, year fixed effects, and full controls. Controls include indicators for LPN, male, race category, education category, a quadradic in age, indicators for single

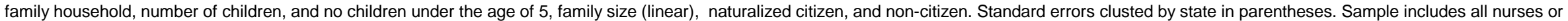

health professionals in the 1990 and 2000 Census (5\% sample) and 2001-2012 ACS. ${ }^{* *} p<0.01,{ }^{*} p<0.05,{ }^{*} p<0.1$ 
Table 3. Main Results for Full Sample

Continous Treatment

\begin{tabular}{|c|c|c|c|c|c|c|c|c|c|c|c|c|c|c|}
\hline & \multicolumn{2}{|c|}{$\begin{array}{c}\text { In labor force } \\
\text { (current) }\end{array}$} & \multicolumn{2}{|c|}{$\begin{array}{l}\text { Employed } \\
\text { (current) }\end{array}$} & \multicolumn{2}{|c|}{$\begin{array}{c}\text { Usual hours worked } \\
\text { (last year) }\end{array}$} & \multicolumn{2}{|c|}{$\begin{array}{c}\text { Log(Wage income) } \\
\text { (last year) }\end{array}$} & \multicolumn{2}{|c|}{$\begin{array}{c}\text { Work in different } \\
\text { state }\end{array}$} & \multicolumn{2}{|c|}{$\begin{array}{l}\text { Work in different } \\
\text { compact state }\end{array}$} & \multicolumn{2}{|c|}{$\begin{array}{c}\text { Log(Commute time) } \\
\text { (current) }\end{array}$} \\
\hline & (1) & (2) & (3) & (4) & (5) & (6) & (7) & (8) & (9) & (10) & (11) & (12) & (13) & (14) \\
\hline \multirow{2}{*}{ Treatment } & $-0.0202^{*}$ & -0.0121 & -0.0191 & -0.0085 & $-1.0994^{\star \star \star}$ & $-1.0127^{\star \star}$ & -0.0343 & -0.0461 & -0.0023 & -0.0059 & 0.0117 & 0.0071 & -0.0413 & $-0.0426^{*}$ \\
\hline & $(0.0106)$ & $(0.0078)$ & $(0.0114)$ & $(0.0095)$ & $(0.4054)$ & $(0.4494)$ & $(0.0376)$ & $(0.0393)$ & $(0.0069)$ & $(0.0078)$ & $(0.0085)$ & $(0.0072)$ & $(0.0263)$ & $(0.0222)$ \\
\hline \multirow[t]{2}{*}{ Nurse } & & 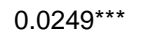 & & $0.0341^{\star \star \star}$ & & $0.9195^{\star \star \star}$ & & $0.3491^{\star \star \star}$ & & $0.0058^{* * *}$ & & 0.0006 & & $0.0555^{\star \star \star}$ \\
\hline & & $(0.0017)$ & & $(0.0018)$ & & $(0.0927)$ & & $(0.0129)$ & & $(0.0020)$ & & $(0.0004)$ & & $(0.0088)$ \\
\hline \multirow[t]{2}{*}{ Treatment $X$ Nurse } & & -0.0026 & & -0.0059 & & 1.2608 & & 0.0598 & & 0.0027 & & 0.0055 & & 0.1119 ** \\
\hline & & $(0.0068)$ & & $(0.0096)$ & & $(0.7593)$ & & $(0.0810)$ & & $(0.0092)$ & & $(0.0040)$ & & $(0.0423)$ \\
\hline Observations & 680,588 & $1,824,791$ & 680,588 & $1,824,791$ & 680,588 & $1,824,791$ & 617,305 & $1,602,769$ & 564,580 & $1,482,355$ & 564,580 & $1,482,355$ & 559,723 & $1,458,395$ \\
\hline R-squared & 0.1282 & 0.0933 & 0.1159 & 0.0788 & 0.1259 & 0.1223 & 0.1557 & 0.2971 & 0.0381 & 0.0333 & 0.0179 & 0.0195 & 0.0295 & 0.0407 \\
\hline Sample & Nurses & All health & Nurses & All health & Nurses & All health & Nurses & All health & Nurses & All health & Nurses & All health & Nurses & All health \\
\hline Outcome mean & 0.884 & 0.871 & 0.867 & 0.842 & 34.41 & 34.40 & 10.30 & 10.02 & 0.035 & 0.030 & 0.008 & 0.008 & 2.97 & 2.93 \\
\hline
\end{tabular}

Notes: All specifications include state fixed effects, year fixed effects, and full controls. Controls include indicators for LPN, male, race category, education category, a quadradic in age, indicators for

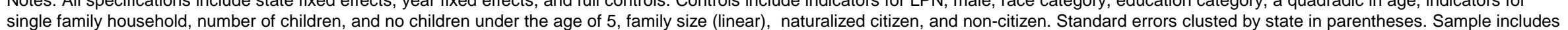
all nurses or health professionals in the 1990 and 2000 Census (5\% sample) and 2001-2012 ACS. ${ }^{* \star *} p<0.01,{ }^{\star *} p<0.05,{ }^{*} p<0.1$ 
Table 4. State-level Migration Results

\begin{tabular}{|c|c|c|c|c|c|c|c|c|}
\hline & \multicolumn{2}{|c|}{ All workers } & \multicolumn{2}{|c|}{ Very mobile workers } & \multicolumn{2}{|c|}{ Low Wage States } & \multicolumn{2}{|c|}{ "High Wage States } \\
\hline & Nurses & All health & Nurses & All health & Nurses & All Health & Nurses & All Health \\
\hline & (1) & (2) & (3) & (4) & (5) & (6) & (7) & $(8)$ \\
\hline \multicolumn{9}{|c|}{ Panel A. Moved to Any State } \\
\hline Treatment & $\begin{array}{c}-0.0032 \\
(0.0057)\end{array}$ & $\begin{array}{l}-0.0009 \\
(0.0037)\end{array}$ & $\begin{array}{c}0.0146 \\
(0.0190)\end{array}$ & $\begin{array}{l}-0.0009 \\
(0.0125)\end{array}$ & $\begin{array}{c}-0.0010 \\
(0.0055)\end{array}$ & $\begin{array}{c}0.0021 \\
(0.0046)\end{array}$ & $\begin{array}{c}0.0060 \\
(0.0038)\end{array}$ & $\begin{array}{c}0.0002 \\
(0.0031)\end{array}$ \\
\hline Nurse & & $\begin{array}{c}0.0008 \\
(0.0008)\end{array}$ & & $\begin{array}{c}0.0028 \\
(0.0025)\end{array}$ & & $\begin{array}{c}0.0006 \\
(0.0008)\end{array}$ & & $\begin{array}{l}-0.0008 \\
(0.0005)\end{array}$ \\
\hline Treatment $X$ Nurse & & $\begin{array}{l}-0.0024 \\
(0.0030)\end{array}$ & & $\begin{array}{c}0.0038 \\
(0.0078)\end{array}$ & & $\begin{array}{c}0.0004 \\
(0.0038)\end{array}$ & & $\begin{array}{c}0.0021 \\
(0.0015)\end{array}$ \\
\hline Outcome mean & 0.023 & 0.027 & 0.057 & 0.056 & 0.023 & 0.026 & 0.022 & 0.026 \\
\hline \multicolumn{9}{|c|}{ Panel B. Moved to Compact State } \\
\hline Treatment & $\begin{array}{c}0.0028 \\
(0.0030)\end{array}$ & $\begin{array}{l}-0.0001 \\
(0.0026)\end{array}$ & $\begin{array}{c}0.0097 \\
(0.0136)\end{array}$ & $\begin{array}{l}-0.0002 \\
(0.0083)\end{array}$ & $\begin{array}{c}0.0024 \\
(0.0080)\end{array}$ & $\begin{array}{c}0.0023 \\
(0.0082)\end{array}$ & $\begin{array}{c}-0.0051 \\
(0.0083)\end{array}$ & $\begin{array}{l}-0.0115 \\
(0.0082)\end{array}$ \\
\hline Nurse & & $\begin{array}{c}0.0009^{*} \\
(0.0005)\end{array}$ & & $\begin{array}{c}0.0021 \\
(0.0016)\end{array}$ & & $\begin{array}{c}0.0013 \\
(0.0009)\end{array}$ & & $\begin{array}{c}0.0007 \\
(0.0008)\end{array}$ \\
\hline Treatment $X$ Nurse & & $\begin{array}{c}0.0005 \\
(0.0020)\end{array}$ & & $\begin{array}{c}0.0083 \\
(0.0061)\end{array}$ & & $\begin{array}{c}0.0002 \\
(0.0033)\end{array}$ & & $\begin{array}{c}0.0029 \\
(0.0022)\end{array}$ \\
\hline Outcome mean & 0.008 & 0.009 & 0.021 & 0.020 & 0.010 & 0.010 & 0.012 & 0.014 \\
\hline $\begin{array}{l}\text { Observations } \\
\text { State FE }\end{array}$ & $\begin{array}{c}379,763 \\
\text { yes }\end{array}$ & $\begin{array}{c}1,004,596 \\
\text { yes }\end{array}$ & $\begin{array}{c}48,420 \\
\text { yes }\end{array}$ & $\begin{array}{c}200,915 \\
\text { yes }\end{array}$ & $\begin{array}{c}120,383 \\
\text { yes }\end{array}$ & $\begin{array}{c}318,462 \\
\text { yes }\end{array}$ & $\begin{array}{c}145,138 \\
\text { yes }\end{array}$ & $\begin{array}{c}383,048 \\
\text { yes }\end{array}$ \\
\hline $\begin{array}{l}\text { Notes: All specificati } \\
\text { in age, indicators for } \\
\text { Standard errors clus } \\
\text { prior year. Treatmen } \\
\text { Other states are we } \\
\text { predicted likelihood }\end{array}$ & ull cont & $\begin{array}{l}\text { Controls i } \\
\text { and no chil }\end{array}$ & ndicat & $\begin{array}{l}\text { of LPN, } n \\
\text { of } 5 \text {, fan } \\
\text { hals in the } \\
\text { with ind } \\
\text { nsus. Ve }\end{array}$ & $\begin{array}{l}\text { ace cate } \\
\text { e (linear } \\
\text {-2012 A } \\
\text { for curre } \\
\text { jile work }\end{array}$ & $\begin{array}{l}\text { ry, educat } \\
\text { naturalize } \\
S \text { that lived } \\
\text { state bein } \\
\text { s are thos }\end{array}$ & $\begin{array}{l}\text { tegory, } \\
\text { en, and } \\
\text { US state } \\
\text { t of the C } \\
\text { le top qu }\end{array}$ & $\begin{array}{l}\text { uadradic } \\
\text { 1-citizen. } \\
\text { r DC) in } \\
\text { npact. } \\
\text { le of }\end{array}$ \\
\hline
\end{tabular}




\section{Table 5. Results for Border County Sample}

\begin{tabular}{|c|c|c|c|c|c|c|c|c|c|c|c|c|c|c|}
\hline & \multicolumn{2}{|c|}{$\begin{array}{c}\text { Tn labor force } \\
\text { (current) }\end{array}$} & \multicolumn{2}{|c|}{$\begin{array}{l}\text { Employed } \\
\text { (current) }\end{array}$} & \multicolumn{2}{|c|}{$\begin{array}{c}\text { Usual hours worked } \\
\text { (last year) }\end{array}$} & \multicolumn{2}{|c|}{$\begin{array}{c}\text { Log(Wage income) } \\
\text { (last year) }\end{array}$} & \multicolumn{2}{|c|}{$\begin{array}{l}\text { Work in different } \\
\text { state }\end{array}$} & \multicolumn{2}{|c|}{$\begin{array}{l}\text { Work in different } \\
\text { compact state }\end{array}$} & \multicolumn{2}{|c|}{$\begin{array}{c}\text { Log(Commute time) } \\
\text { (current) }\end{array}$} \\
\hline & (1) & (2) & (3) & (4) & $(5)$ & (6) & $(7)$ & $(8)$ & (9) & $(10)$ & $(11)$ & $(12)$ & $(13)$ & $(14)$ \\
\hline Resident \& border state both Compact & $\begin{array}{l}-0.0072 \\
(0.0066)\end{array}$ & $\begin{array}{l}-0.0063 \\
(0.0073)\end{array}$ & $\begin{array}{l}-0.0117 \\
(0.0071)\end{array}$ & $\begin{array}{l}-0.0047 \\
(0.0092)\end{array}$ & $\begin{array}{l}-0.2956 \\
(0.3180)\end{array}$ & $\begin{array}{l}-0.4571 \\
(0.3134)\end{array}$ & $\begin{array}{l}-0.0431^{*} \\
(0.0217)\end{array}$ & $\begin{array}{l}-0.0086 \\
(0.0139)\end{array}$ & $\begin{array}{l}-0.0201 \\
(0.0122)\end{array}$ & $\begin{array}{l}-0.0181 \\
(0.0137)\end{array}$ & $\begin{array}{l}0.0220^{\star \star \star} \\
(0.0071)\end{array}$ & $\begin{array}{l}0.0300^{\star \star *} \\
(0.0075)\end{array}$ & $\begin{array}{l}-0.0536^{* *} \\
(0.0256)\end{array}$ & $\begin{array}{l}-0.0532^{\star \star \star} \\
(0.0155)\end{array}$ \\
\hline Nurse & & $\begin{array}{c}0.0210^{* \star *} \\
(0.0027)\end{array}$ & & $\begin{array}{l}0.0297^{\star \star \star} \\
(0.0029)\end{array}$ & & $\begin{array}{l}0.8340^{\star * *} \\
(0.1359)\end{array}$ & & $\begin{array}{l}0.3503^{\star \star *} \\
(0.0175)\end{array}$ & & $\begin{array}{l}0.0065 \\
(0.0050)\end{array}$ & & $\begin{array}{l}-0.0002 \\
(0.0010)\end{array}$ & & $\begin{array}{l}0.0288^{*} \\
(0.0156)\end{array}$ \\
\hline Resident \& border state both Compact X Nur & & $\begin{array}{l}-0.0039 \\
(0.0066)\end{array}$ & & $\begin{array}{l}-0.0094 \\
(0.0066)\end{array}$ & & $\begin{array}{c}0.0397 \\
(0.2535)\end{array}$ & & $\begin{array}{l}-0.0379 \\
(0.0287)\end{array}$ & & $\begin{array}{c}0.0076 \\
(0.0092)\end{array}$ & & $\begin{array}{l}-0.0070 \\
(0.0043)\end{array}$ & & $\begin{array}{c}0.0281 \\
(0.0246)\end{array}$ \\
\hline Observations & 127,633 & 348,472 & 127,633 & 348,472 & 127,633 & 348,472 & 115,990 & 307,219 & 106,284 & 284,578 & 106,284 & 284,578 & 105,366 & 280,485 \\
\hline R-squared & 0.1354 & 0.0882 & 0.1211 & 0.0813 & 0.1316 & 0.1205 & 0.1551 & 0.2944 & 0.1739 & 0.1421 & 0.1574 & 0.1227 & 0.0776 & 0.0975 \\
\hline Sample & Nurses & All health & Nurses & All health & Nurses & All health & Nurses & All health & Nurses & All health & Nurses & All health & Nurses & All health \\
\hline Outcome mean & 0.894 & 0.884 & 0.875 & 0.854 & 34.47 & 34.59 & 10.39 & 10.11 & 0.067 & 0.061 & 0.012 & 0.012 & 3.06 & 3.05 \\
\hline
\end{tabular}

\begin{tabular}{llllllllll} 
Outcome mean & 0.894 & 0.884 & 0.875 & 0.854 & 34.47 & 34.59 & 10.39 & 10.11 & 0.067 \\
\hline \hline Notes: All specifications include county fixed effects, year fixed effects, and full controls. Controls include indicators for LPN, male, race category, education category, a quadradic in age, indicators for single family
\end{tabular}

household, number of children, and no children under the age of 5 , family size (linear), naturalized citizen, and non-citizen. Standard errors clusted by state in parentheses. Sample includes all nurses or health

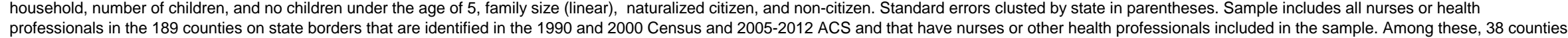
were treated. ${ }^{* \star *} p<0.01,{ }^{* \star} p<0.05,{ }^{*} p<0.1$ 
Table 6. Effect of Residing in and Bordering Compact State

Robustness for Triple Difference with All Health Workers

\begin{tabular}{|c|c|c|c|c|c|c|}
\hline & $\begin{array}{c}\text { Base model } \\
\text { (1) }\end{array}$ & $\begin{array}{c}\text { No controls } \\
\text { (2) }\end{array}$ & $\begin{array}{c}\text { State X Year } \\
\text { FE } \\
\text { (3) }\end{array}$ & $\begin{array}{c}\text { Only NLC } \\
\text { states } \\
(4)\end{array}$ & $\begin{array}{l}\text { Only treated } \\
\text { counties } \\
\text { (5) }\end{array}$ & $\begin{array}{c}\text { Cluster by } \\
\text { county } \\
(6)\end{array}$ \\
\hline \multicolumn{7}{|c|}{ Panel A. In labor force (mean $=.884)$} \\
\hline $\begin{array}{r}\text { Coeff } \\
(\mathrm{SE})\end{array}$ & $\begin{array}{l}-0.0039 \\
(0.0066)\end{array}$ & $\begin{array}{l}-0.0034 \\
(0.0056)\end{array}$ & $\begin{array}{l}-0.0031 \\
(0.0068)\end{array}$ & $\begin{array}{l}-0.0002 \\
(0.0071)\end{array}$ & $\begin{array}{c}0.0038 \\
(0.0075)\end{array}$ & $\begin{array}{l}-0.0039 \\
(0.0062)\end{array}$ \\
\hline \multicolumn{7}{|c|}{ Panel B. Employed (mean $=.854)$} \\
\hline $\begin{array}{r}\text { Coeff } \\
\text { (SE) }\end{array}$ & $\begin{array}{l}-0.0094 \\
(0.0066)\end{array}$ & $\begin{array}{l}-0.0089 \\
(0.0058)\end{array}$ & $\begin{array}{l}-0.0083 \\
(0.0069)\end{array}$ & $\begin{array}{l}-0.0054 \\
(0.0076)\end{array}$ & $\begin{array}{l}-0.0010 \\
(0.0091)\end{array}$ & $\begin{array}{l}-0.0094 \\
(0.0066)\end{array}$ \\
\hline \multicolumn{7}{|c|}{ Panel C. Usual hours worked (mean $=34.59)$} \\
\hline $\begin{array}{r}\text { Coeff } \\
(\mathrm{SE})\end{array}$ & $\begin{array}{c}0.0397 \\
(0.2535)\end{array}$ & $\begin{array}{c}0.1823 \\
(0.2793)\end{array}$ & $\begin{array}{c}0.0279 \\
(0.2517)\end{array}$ & $\begin{array}{c}0.8687^{\star \star *} \\
(0.2082)\end{array}$ & $\begin{array}{c}1.6866^{\star \star *} \\
(0.3644)\end{array}$ & $\begin{array}{c}0.0397 \\
(0.2453)\end{array}$ \\
\hline \multicolumn{7}{|c|}{ Panel D. Log (wage income) (mean $=10.11)$} \\
\hline $\begin{array}{r}\text { Coeff } \\
(\mathrm{SE})\end{array}$ & $\begin{array}{c}-0.0379 \\
(0.0287)\end{array}$ & $\begin{array}{l}-0.0442 \\
(0.0384)\end{array}$ & $\begin{array}{l}-0.0362 \\
(0.0285)\end{array}$ & $\begin{array}{c}0.0247 \\
(0.0235)\end{array}$ & $\begin{array}{c}0.1004^{* * *} \\
(0.0310)\end{array}$ & $\begin{array}{l}-0.0379 \\
(0.0246)\end{array}$ \\
\hline \multicolumn{7}{|c|}{ Panel E. Work in different state (mean $=.0605)$} \\
\hline $\begin{array}{r}\text { Coeff } \\
(\mathrm{SE})\end{array}$ & $\begin{array}{c}0.0076 \\
(0.0092)\end{array}$ & $\begin{array}{c}0.0074 \\
(0.0094)\end{array}$ & $\begin{array}{c}0.0072 \\
(0.0093)\end{array}$ & $\begin{array}{c}0.0136 \\
(0.0084)\end{array}$ & $\begin{array}{l}-0.0020 \\
(0.0050)\end{array}$ & $\begin{array}{c}0.0076 \\
(0.0078)\end{array}$ \\
\hline \multicolumn{7}{|c|}{ Panel F. Work in different compact state $($ mean $=.012)$} \\
\hline $\begin{array}{r}\text { Coeff } \\
(\mathrm{SE})\end{array}$ & $\begin{array}{l}-0.0070 \\
(0.0043)\end{array}$ & $\begin{array}{l}-0.0070 \\
(0.0043)\end{array}$ & $\begin{array}{l}-0.0073^{*} \\
(0.0042)\end{array}$ & $\begin{array}{l}-0.0075^{\star} \\
(0.0042)\end{array}$ & $\begin{array}{l}-0.0078 \\
(0.0053)\end{array}$ & $\begin{array}{l}-0.0070 * \\
(0.0038)\end{array}$ \\
\hline \multicolumn{7}{|c|}{ Panel G. Log(Commute time) (mean $=3.052)$} \\
\hline $\begin{array}{r}\text { Coeff } \\
(\mathrm{SE})\end{array}$ & $\begin{array}{c}0.0281 \\
(0.0246)\end{array}$ & $\begin{array}{c}0.0281 \\
(0.0276)\end{array}$ & $\begin{array}{c}0.0286 \\
(0.0235)\end{array}$ & $\begin{array}{c}0.0046 \\
(0.0174)\end{array}$ & $\begin{array}{l}-0.0123 \\
(0.0200)\end{array}$ & $\begin{array}{c}0.0281 \\
(0.0189)\end{array}$ \\
\hline Observations & 348,472 & 348,472 & 348,472 & 97,932 & 48,482 & 348,472 \\
\hline Number of states & 44 & 44 & 44 & 22 & 16 & 44 \\
\hline Number of counties & 189 & 189 & 189 & 70 & 38 & 189 \\
\hline
\end{tabular}

Notes: Each cell presents the coefficient and standard error on the interaction between Nurse and an indicator for living in and bordering a compact state from a separate regression. All specifications include year fixed effects, county fixed effects, Nurse, indicator for living in and bordering a compact state, and (except column 2) full controls. Controls include indicators for LPN, male, race category, education category, a quadradic in age, indicators for single family household, number of children, and no children under the age of 5 , family size (linear), naturalized citizen, and non-citizen. Standard errors clusted by state (county in specification 6) in parentheses. Sample includes all health workers in the 189 counties on state borders that are identified in the Census and ACS and have nurses in the sample. Reported sample size is for Panels A and B. Subsequent panels have smaller sample sizes as they are conditional on being employed or having positive income. ${ }^{* \star} p<0.01,{ }^{* *} p<0.05,{ }^{*} p<0.1$ 
Table 7: Effect of Nurse Licensure Compact on Nurse Labor Supply Results (using AHA data)

\begin{tabular}{|c|c|c|c|c|c|c|}
\hline & \multicolumn{2}{|c|}{$\begin{array}{l}\text { Log Full-time Equivalent } \\
\text { LPNs }\end{array}$} & \multicolumn{2}{|c|}{$\begin{array}{l}\text { Log Full-time Equivalent } \\
\text { RNs }\end{array}$} & \multicolumn{2}{|c|}{$\begin{array}{l}\text { Log Full-time Equivalent } \\
\text { Nurses }\end{array}$} \\
\hline & (1) & $(2)$ & (3) & $(4)$ & (5) & (6) \\
\hline \multicolumn{7}{|c|}{ Panel A: Aggregate Hospital Nurse Hours } \\
\hline \multirow[t]{2}{*}{ Compact State } & 0.0012 & & -0.0016 & & -0.0071 & \\
\hline & $(0.0264)$ & & $(0.0148)$ & & $(0.0146)$ & \\
\hline \multirow[t]{2}{*}{ Treatment } & & 0.0585 & & -0.0061 & & -0.0236 \\
\hline & & $(0.0884)$ & & $(0.0571)$ & & $(0.0564)$ \\
\hline Observations & 89,451 & 89,451 & 92,395 & 92,395 & 92,419 & 92,419 \\
\hline R-squared & 0.8148 & 0.8148 & 0.9610 & 0.9610 & 0.9613 & 0.9613 \\
\hline \multirow[t]{3}{*}{ Y mean } & 2.6899 & 2.6899 & 4.4071 & 4.4071 & 4.6293 & 4.6293 \\
\hline & \multicolumn{2}{|c|}{$\begin{array}{c}\text { Full-time Equivalent LPNs } \\
\text { per Admission }\end{array}$} & \multicolumn{2}{|c|}{$\begin{array}{c}\text { Full-time Equivalent RNs } \\
\text { per Admission }\end{array}$} & \multicolumn{2}{|c|}{$\begin{array}{l}\text { Full-time Equivalent } \\
\text { Nurses per Admission }\end{array}$} \\
\hline & (1) & $(2)$ & (3) & $(4)$ & (5) & $(6)$ \\
\hline \multicolumn{7}{|c|}{ Panel B: Aggregate Hospital Nurse Hours (Normalized) } \\
\hline \multirow[t]{2}{*}{ Compact State } & -0.0001 & & -0.0001 & & -0.0004 & \\
\hline & $(0.0037)$ & & $(0.0037)$ & & $(0.0070)$ & \\
\hline \multirow[t]{2}{*}{ Treatment } & & 0.0046 & & 0.0086 & & 0.0128 \\
\hline & & $(0.0122)$ & & $(0.0124)$ & & $(0.0234)$ \\
\hline Observations & 89,444 & 89,444 & 92,388 & 92,388 & 92,412 & 92,412 \\
\hline R-squared & 0.491 & 0.4910 & 0.1856 & 0.1856 & 0.3581 & 0.3581 \\
\hline Y mean & 0.0158 & 0.0158 & 0.0331 & 0.0331 & 0.0483 & 0.0483 \\
\hline
\end{tabular}

Notes: All specifications include hospital fixed effects, year fixed effects, and controls for whether a hospital is in a system, ownership type, total hospital beds, total inpatient days, and adjusted admissions (in panel A only). Omitted hospital ownership category is "government-owned." Standard errors clusted by state in parentheses. Sample includes all hospitals surveyed by the AHA in the United States for years $1995-2009$. ${ }^{\star * \star} p<0.01,{ }^{* \star} p<0.05,{ }^{*} p<0.1$ 
Table A1. Implementation Dates for Nurse Licensure Compact States

\begin{tabular}{cc}
\hline \hline & Date of implementation \\
Arizona & $7 / 1 / 2002$ \\
Arkansas & $7 / 1 / 2000$ \\
Colorado & $10 / 1 / 2007$ \\
Delaware & $7 / 1 / 2000$ \\
Idaho & $7 / 1 / 2001$ \\
lowa & $7 / 1 / 2000$ \\
Kentucky & $6 / 1 / 2007$ \\
Maine & $7 / 1 / 2001$ \\
Maryland & $7 / 1 / 1999$ \\
Mississippi & $7 / 1 / 2001$ \\
Missouri & $6 / 1 / 2010$ \\
Montana & $10 / 1 / 2015$ \\
Nebraska & $1 / 1 / 2001$ \\
New Hampshire & $1 / 1 / 2006$ \\
New Mexico & $1 / 1 / 2004$ \\
North Carolina & $7 / 1 / 2000$ \\
North Dakota & $1 / 1 / 2004$ \\
Rhode Island & $7 / 1 / 2008$ \\
South Carolina & $2 / 1 / 2006$ \\
South Dakota & $1 / 1 / 2001$ \\
Tennessee & $7 / 1 / 2003$ \\
Texas & $1 / 1 / 2000$ \\
Utah & $1 / 1 / 2000$ \\
Virginia & $1 / 1 / 2005$ \\
Wisconsin & $1 / 1 / 2000$ \\
\hline \hline
\end{tabular}

states with egistation pending include litinois, Massachusetts, Minnesota, New Jersey, New York, and Oklahoma.

Source: https://www.ncsbn.org/nurse-licensure-compact.htm 
Table A2. Main Labor Supply Results for Full Sample, by MSA

\begin{tabular}{|c|c|c|c|c|c|c|c|c|c|c|c|c|c|c|}
\hline & \multicolumn{2}{|c|}{$\begin{array}{l}\text { In labor force } \\
\text { (current) }\end{array}$} & \multicolumn{2}{|c|}{$\begin{array}{l}\text { Employed } \\
\text { (current) }\end{array}$} & \multicolumn{2}{|c|}{$\begin{array}{l}\text { Usual hours worked } \\
\text { (last year) }\end{array}$} & \multicolumn{2}{|c|}{$\begin{array}{c}\text { Log(Wage Income) } \\
\text { (last year) }\end{array}$} & \multicolumn{2}{|c|}{$\begin{array}{l}\text { Work in different } \\
\text { state }\end{array}$} & \multicolumn{2}{|c|}{$\begin{array}{l}\text { Work In different } \\
\text { compact state }\end{array}$} & \multicolumn{2}{|c|}{$\begin{array}{c}\text { Log(Commute tıme) } \\
\text { (current) }\end{array}$} \\
\hline & (1) & (2) & (3) & (4) & (5) & (6) & (7) & (8) & (9) & (10) & (11) & (12) & (13) & (14) \\
\hline Panel A. MSA & & & & & & & & & & & & & & \\
\hline Treatment & $\begin{array}{l}-0.0318^{\star *} \\
(0.0131)\end{array}$ & $\begin{array}{c}-0.0320^{\star \star \star *} \\
(0.0107)\end{array}$ & $\begin{array}{l}-0.0369 * \star \\
(0.0144)\end{array}$ & $\begin{array}{l}-0.0264^{*} \\
(0.0134)\end{array}$ & $\begin{array}{c}-1.4174^{\star \star \star} \\
(0.5059)\end{array}$ & $\begin{array}{l}-1.4858^{\star \star} \\
(0.6001)\end{array}$ & $\begin{array}{l}-0.0280 \\
(0.0484)\end{array}$ & $\begin{array}{l}-0.0389 \\
(0.0450)\end{array}$ & $\begin{array}{l}-0.0095 \\
(0.0120)\end{array}$ & $\begin{array}{l}-0.0037 \\
(0.0099)\end{array}$ & $\begin{array}{c}0.0060 \\
(0.0091)\end{array}$ & $\begin{array}{c}0.0069 \\
(0.0079)\end{array}$ & $\begin{array}{r}-0.0440 \\
(0.0297)\end{array}$ & $\begin{array}{l}-0.0707^{\star *} \\
(0.0282)\end{array}$ \\
\hline Nurse & & $\begin{array}{c}0.0223^{\star \star *} \\
(0.0014)\end{array}$ & & $\begin{array}{c}0.0325^{\star \star \star} \\
(0.0018)\end{array}$ & & $\begin{array}{l}1.0333^{\star \star \star} \\
(0.0909)\end{array}$ & & $\begin{array}{l}0.3623^{\star \star *} \\
(0.0154)\end{array}$ & & $\begin{array}{l}0.0047^{\star} \\
(0.0024)\end{array}$ & & $\begin{array}{l}-0.0001 \\
(0.0005)\end{array}$ & & $\begin{array}{c}0.0393^{\star \star \star} \\
(0.0098)\end{array}$ \\
\hline Treatment $X$ Nurse & & $\begin{array}{c}0.0016 \\
(0.0098)\end{array}$ & & $\begin{array}{l}-0.0030 \\
(0.0132)\end{array}$ & & $\begin{array}{l}1.1816 \\
(1.0055)\end{array}$ & & $\begin{array}{c}0.0590 \\
(0.0992)\end{array}$ & & $\begin{array}{l}-0.0043 \\
(0.0100)\end{array}$ & & $\begin{array}{l}-0.0009 \\
(0.0045)\end{array}$ & & $\begin{array}{l}0.1069^{\star *} \\
(0.0428)\end{array}$ \\
\hline Observations & 378,229 & $1,034,563$ & 378,229 & $1,034,563$ & 378,229 & $1,034,563$ & 343,505 & 909,059 & 314,830 & 844,958 & 314,830 & 844,958 & 312,013 & 831,428 \\
\hline Sample & Nurses & All health & Nurses & All health & Nurses & All health & Nurses & All health & Nurses & All health & Nurses & All health & Nurses & All health \\
\hline Outcome mean & 0.892 & 0.881 & 0.875 & 0.852 & 34.570 & 34.465 & 10.363 & 10.064 & 0.029 & 0.026 & 0.005 & 0.005 & 3.012 & 2.980 \\
\hline Panel B. Non-MSA & & & & & & & & & & & & & & \\
\hline Treatment & $\begin{array}{l}-0.0230^{*} \\
(0.0115)\end{array}$ & $\begin{array}{c}0.0068 \\
(0.0128)\end{array}$ & $\begin{array}{l}-0.0179 \\
(0.0125)\end{array}$ & $\begin{array}{c}0.0106 \\
(0.0189)\end{array}$ & $\begin{array}{l}-0.8927 \\
(0.6042)\end{array}$ & $\begin{array}{l}-0.6504 \\
(0.6727)\end{array}$ & $\begin{array}{l}-0.0616 \\
(0.0474)\end{array}$ & $\begin{array}{l}-0.0483 \\
(0.0548)\end{array}$ & $\begin{array}{c}0.0135 \\
(0.0116)\end{array}$ & $\begin{array}{c}0.0090 \\
(0.0111)\end{array}$ & $\begin{array}{r}0.0103 \\
(0.0121)\end{array}$ & $\begin{array}{c}0.0044 \\
(0.0079)\end{array}$ & $\begin{array}{l}-0.0845^{\star \star} \\
(0.0393)\end{array}$ & $\begin{array}{l}-0.0655 \\
(0.0431)\end{array}$ \\
\hline Nurse & & $\begin{array}{c}0.0220^{\star \star *} \\
(0.0023)\end{array}$ & & $\begin{array}{l}0.0295^{\star \star *} \\
(0.0027)\end{array}$ & & $\begin{array}{l}0.8255^{\star \star \star} \\
(0.1216)\end{array}$ & & $\begin{array}{l}0.3073^{\star * *} \\
(0.0105)\end{array}$ & & $\begin{array}{r}0.0079 * * * \\
(0.0020)\end{array}$ & & $\begin{array}{l}0.0033^{\star *} \\
(0.0014)\end{array}$ & & $\begin{array}{c}0.0942^{\star \star *} \\
(0.0073)\end{array}$ \\
\hline Treatment $X$ Nurse & & $\begin{array}{l}-0.0145 \\
(0.0097)\end{array}$ & & $\begin{array}{l}-0.0121 \\
(0.0110)\end{array}$ & & $\begin{array}{l}0.5697 \\
(0.4760)\end{array}$ & & $\begin{array}{c}0.0507 \\
(0.0449)\end{array}$ & & $\begin{array}{l}0.0125 \\
(0.0108)\end{array}$ & & $\begin{array}{l}0.0095 \\
(0.0076)\end{array}$ & & $\begin{array}{c}0.0239 \\
(0.0301)\end{array}$ \\
\hline Observations & 204,314 & 513,225 & 204,314 & 513,225 & 204,314 & 513,225 & 184,516 & 449,637 & 169,704 & 418,448 & 169,704 & 418,448 & 168,221 & 412,004 \\
\hline Sample & Nurses & All health & Nurses & All health & Nurses & All health & Nurses & All health & Nurses & All health & Nurses & All health & Nurses & All health \\
\hline Outcome mean & 0.885828 & 0.879 & 0.867 & 0.852 & 34.118 & 34.471 & 10.222 & 10.028 & 0.048 & 0.043 & 0.018 & 0.015 & 2.945 & 2.864 \\
\hline
\end{tabular}

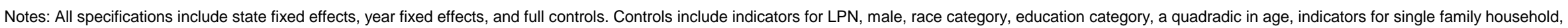
number of children, and no children under the age of 5 , family size (linear), naturalized citizen, and non-citizen. Standard errors clusted by state in parentheses. Sample includes all nurses or health professionals in the 1990 and 2000 Census (5\% sample) and 2006-2012 ACS. ${ }^{* * *} p<0.01,{ }^{* *} p<0.05,{ }^{*} p<0.1$ 
Table A3 Complete Labor Supply Results for Full Sample, Nurses Only

\begin{tabular}{|c|c|c|c|c|c|c|c|}
\hline & $\begin{array}{c}\text { In labor force } \\
\text { (current) }\end{array}$ & $\begin{array}{c}\text { Employed } \\
\text { (current) }\end{array}$ & $\begin{array}{l}\text { Usual hours } \\
\text { worked } \\
\text { (last year) }\end{array}$ & $\begin{array}{c}\text { Log(Wage } \\
\text { income) } \\
\text { (last year) }\end{array}$ & $\begin{array}{c}\text { Work in } \\
\text { different state } \\
\text { (current) }\end{array}$ & $\begin{array}{c}\text { Work in } \\
\text { different } \\
\text { compact state }\end{array}$ & $\begin{array}{c}\text { Log(Commute } \\
\text { time) } \\
\text { (current) }\end{array}$ \\
\hline \multirow[t]{2}{*}{ Compact state } & $-0.0106^{\star \star \star}$ & $-0.0113^{\star \star \star}$ & $-0.4139^{\star \star}$ & -0.0089 & -0.0002 & $0.0056^{*}$ & -0.0103 \\
\hline & $(0.0037)$ & $(0.0041)$ & $(0.1549)$ & $(0.0137)$ & $(0.0028)$ & $(0.0031)$ & $(0.0077)$ \\
\hline \multirow[t]{2}{*}{ LPN } & $-0.0223^{\star \star \star}$ & $-0.0324^{\star \star *}$ & $-0.5661^{\star \star \star}$ & $-0.3568^{\star \star *}$ & $-0.0059^{\star \star \star}$ & -0.0010 & $-0.0609 * \star \star$ \\
\hline & $(0.0023)$ & $(0.0025)$ & $(0.1003)$ & $(0.0075)$ & $(0.0016)$ & $(0.0006)$ & $(0.0075)$ \\
\hline \multirow[t]{2}{*}{ Male } & $0.0193^{\star \star \star}$ & $0.0169^{\star \star *}$ & $3.4772^{\star \star \star}$ & $0.1752^{\star \star \star}$ & $0.0088^{\star \star *}$ & 0.0012 & $0.0571^{\star \star \star}$ \\
\hline & $(0.0017)$ & $(0.0025)$ & $(0.1795)$ & $(0.0141)$ & $(0.0026)$ & $(0.0010)$ & $(0.0088)$ \\
\hline \multirow[t]{2}{*}{ White } & $0.0151^{\star \star *}$ & $0.0259^{\star * *}$ & $-0.6777^{\star \star \star}$ & -0.0036 & $-0.0118^{* *}$ & -0.0037 & $-0.0490^{\star \star *}$ \\
\hline & $(0.0044)$ & $(0.0049)$ & $(0.2389)$ & $(0.0121)$ & $(0.0055)$ & $(0.0032)$ & $(0.0176)$ \\
\hline \multirow[t]{2}{*}{ Black } & $0.0270^{\star \star \star}$ & $0.0274^{\star \star \star}$ & $1.0182^{\star \star \star}$ & 0.0262 & -0.0070 & $-0.0057^{*}$ & $0.0561^{\star \star}$ \\
\hline & $(0.0053)$ & $(0.0060)$ & $(0.1675)$ & $(0.0181)$ & $(0.0060)$ & $(0.0031)$ & $(0.0240)$ \\
\hline \multirow[t]{2}{*}{ Amer. Indian } & -0.0103 & -0.0134 & 0.7121 & -0.0135 & 0.0088 & 0.0037 & -0.0302 \\
\hline & $(0.0105)$ & $(0.0116)$ & $(0.4306)$ & $(0.0265)$ & $(0.0077)$ & $(0.0060)$ & $(0.0372)$ \\
\hline \multirow[t]{2}{*}{ Asian } & $0.0178^{\star \star \star}$ & $0.0294^{\star \star *}$ & 0.6515 & $0.1439^{\star \star \star}$ & $-0.0110^{*}$ & $-0.0055^{*}$ & $-0.0752^{\star \star \star}$ \\
\hline & $(0.0052)$ & $(0.0067)$ & $(0.4039)$ & $(0.0154)$ & $(0.0064)$ & $(0.0031)$ & $(0.0220)$ \\
\hline \multirow[t]{2}{*}{ Other race } & $0.0198^{\star \star \star}$ & $0.0243^{\star \star}$ & 0.4049 & -0.0138 & $-0.0078^{\star *}$ & -0.0045 & -0.0390 \\
\hline & $(0.0067)$ & $(0.0097)$ & $(0.5028)$ & $(0.0267)$ & $(0.0035)$ & $(0.0034)$ & $(0.0305)$ \\
\hline \multirow[t]{2}{*}{ Less than HS } & $-0.0980^{\star * *}$ & $-0.1427^{\star \star \star *}$ & $-4.4644^{\star \star \star}$ & $-0.4206^{\star \star *}$ & -0.0096 & 0.0030 & $-0.0897^{* *}$ \\
\hline & $(0.0105)$ & $(0.0113)$ & $(0.3714)$ & $(0.0247)$ & $(0.0069)$ & $(0.0036)$ & $(0.0344)$ \\
\hline \multirow[t]{2}{*}{ High school } & $-0.0455^{\star \star *}$ & $-0.0575^{\star \star \star}$ & $-2.8143^{\star \star \star}$ & $-0.2914^{\star \star *}$ & $-0.0129^{\star \star \star}$ & $-0.0028^{* *}$ & $-0.0907^{\star * *}$ \\
\hline & $(0.0037)$ & $(0.0038)$ & $(0.1531)$ & $(0.0126)$ & $(0.0038)$ & $(0.0012)$ & $(0.0112)$ \\
\hline \multirow[t]{2}{*}{ Some college } & $-0.0092^{\star * *}$ & $-0.0107^{\star \star *}$ & $-1.6409^{\star \star \star}$ & $-0.1886^{\star * *}$ & $-0.0069^{* *}$ & -0.0007 & $-0.0603^{\star * *}$ \\
\hline & $(0.0018)$ & $(0.0019)$ & $(0.0919)$ & $(0.0061)$ & $(0.0027)$ & $(0.0008)$ & $(0.0078)$ \\
\hline \multirow[t]{2}{*}{ College } & $-0.0070^{\star * *}$ & $-0.0040^{*}$ & $-1.6730^{\star \star \star}$ & $-0.0959^{\star \star \star}$ & $-0.0047^{\star \star \star}$ & -0.0010 & $-0.0334^{\star \star *}$ \\
\hline & $(0.0019)$ & $(0.0020)$ & $(0.1299)$ & $(0.0080)$ & $(0.0012)$ & $(0.0007)$ & $(0.0064)$ \\
\hline \multirow[t]{2}{*}{ Age } & $0.0301^{* * *}$ & $0.0300^{\star * *}$ & $1.3096^{\star \star \star}$ & $0.1074^{\star \star \star}$ & $0.0005^{\star}$ & 0.0001 & $0.0095^{\star * *}$ \\
\hline & $(0.0006)$ & $(0.0006)$ & $(0.0235)$ & $(0.0013)$ & $(0.0003)$ & $(0.0001)$ & $(0.0013)$ \\
\hline \multirow[t]{2}{*}{ Age-squared } & $-0.0004^{\star * \star}$ & $-0.0004^{\star * *}$ & $-0.0172^{\star \star \star}$ & $-0.0012^{\star \star *}$ & $-0.0000^{\star *}$ & -0.0000 & $-0.0001^{\star \star *}$ \\
\hline & $(0.0000)$ & $(0.0000)$ & $(0.0003)$ & $(0.0000)$ & $(0.0000)$ & $(0.0000)$ & $(0.0000)$ \\
\hline \multirow[t]{2}{*}{ Single household } & $0.0113^{\star \star \star}$ & $0.0047^{\star}$ & $1.2077^{\star \star \star}$ & $0.0349^{\star \star \star *}$ & -0.0003 & -0.0005 & $-0.0329 \star \star \star *$ \\
\hline & $(0.0024)$ & $(0.0028)$ & $(0.0993)$ & $(0.0068)$ & $(0.0015)$ & $(0.0009)$ & $(0.0062)$ \\
\hline \multirow[t]{2}{*}{ Family size } & $-0.0025^{\star \star *}$ & $-0.0044^{\star \star *}$ & $-0.4046^{\star \star \star}$ & $-0.0399 * \star *$ & 0.0004 & 0.0002 & $0.0224^{\star \star \star}$ \\
\hline & $(0.0009)$ & $(0.0010)$ & $(0.0675)$ & $(0.0043)$ & $(0.0006)$ & $(0.0003)$ & $(0.0023)$ \\
\hline \multirow[t]{2}{*}{ No children in household } & $0.0200 * *$ & 0.0092 & 0.1319 & -0.0350 & 0.0062 & 0.0006 & $0.1383^{\star \star *}$ \\
\hline & $(0.0090)$ & $(0.0084)$ & $(0.3695)$ & $(0.0336)$ & $(0.0055)$ & $(0.0031)$ & $(0.0266)$ \\
\hline \multirow[t]{2}{*}{ One child in household } & $0.0417^{\star \star \star *}$ & $0.0331^{\star \star \star}$ & $1.2959 * \star \star *$ & 0.0227 & 0.0031 & 0.0007 & $0.1015^{\star \star \star}$ \\
\hline & $(0.0084)$ & $(0.0077)$ & $(0.3365)$ & $(0.0326)$ & $(0.0055)$ & $(0.0031)$ & $(0.0264)$ \\
\hline \multirow[t]{2}{*}{ Two children in household } & $0.0273^{\star \star \star}$ & $0.0233^{\star \star *}$ & -0.2823 & -0.0113 & 0.0004 & 0.0001 & $0.0667^{\star \star \star}$ \\
\hline & $(0.0078)$ & $(0.0076)$ & $(0.3208)$ & $(0.0286)$ & $(0.0054)$ & $(0.0031)$ & $(0.0244)$ \\
\hline \multirow[t]{2}{*}{$3-5$ children in household } & $0.0155^{\star}$ & 0.0116 & $-0.9529^{\star \star \star *}$ & -0.0420 & 0.0006 & -0.0005 & 0.0329 \\
\hline & $(0.0081)$ & $(0.0078)$ & $(0.3416)$ & $(0.0252)$ & $(0.0054)$ & $(0.0028)$ & $(0.0239)$ \\
\hline No children under 5 & $0.0668^{\star \star *}$ & $0.0683^{\star \star \star}$ & 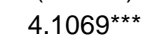 & $0.0429^{\star \star \star}$ & 0.0004 & 0.0010 & $-0.0438^{\star \star *}$ \\
\hline & $(0.0019)$ & $(0.0022)$ & $(0.1167)$ & $(0.0071)$ & $(0.0014)$ & $(0.0008)$ & $(0.0052)$ \\
\hline Nationalized citizen & $0.0147^{\star \star \star *}$ & $0.0217^{\star * *}$ & $1.6452^{\star \star *}$ & $0.0926^{\star \star \star}$ & 0.0063 & $-0.0021^{* *}$ & $0.0906^{\star * *}$ \\
\hline & $(0.0029)$ & $(0.0033)$ & $(0.1667)$ & $(0.0124)$ & $(0.0058)$ & $(0.0010)$ & $(0.0306)$ \\
\hline Not citizen & $-0.0274^{\star \star *}$ & $-0.0273^{\star * \star}$ & 0.1119 & $-0.0760^{\star \star *}$ & 0.0015 & $-0.0024^{\star *}$ & -0.0073 \\
\hline & $(0.0048)$ & $(0.0050)$ & $(0.2371)$ & $(0.0125)$ & $(0.0035)$ & $(0.0010)$ & $(0.0308)$ \\
\hline Observations & 582,543 & 582,543 & 582,543 & 528,021 & 484,534 & 484,534 & 480,234 \\
\hline R-squared & 0.1406 & 0.1267 & 0.1275 & 0.1597 & 0.0380 & 0.0181 & 0.0304 \\
\hline Outcome mean & 0.890 & 0.872 & 34.416 & 10.315 & 0.035 & 0.010 & 2.989 \\
\hline
\end{tabular}


Table A4 First Stage Estimates of Correlates of Labor Force Participation

\begin{tabular}{|c|c|}
\hline \multicolumn{2}{|r|}{ Probit coeff } \\
\hline \multirow[t]{2}{*}{$\overline{\text { Male }}$} & 0.2278 \\
\hline & $(0.0038)$ \\
\hline \multirow[t]{2}{*}{ White } & 0.1027 \\
\hline & $(0.0068)$ \\
\hline \multirow[t]{2}{*}{ Black } & 0.0789 \\
\hline & $(0.0075)$ \\
\hline \multirow[t]{2}{*}{ Asian } & 0.0475 \\
\hline & (0.0089) \\
\hline \multirow[t]{2}{*}{ American Indian } & -0.0126 \\
\hline & (0.0163) \\
\hline \multirow[t]{2}{*}{ Less than high school } & -0.6130 \\
\hline & $(0.0067)$ \\
\hline \multirow[t]{2}{*}{ High school } & -0.3899 \\
\hline & $(0.0047)$ \\
\hline \multirow[t]{2}{*}{ Some college } & -0.1956 \\
\hline & $(0.0044)$ \\
\hline \multirow[t]{2}{*}{ College } & -0.1529 \\
\hline & $(0.0048)$ \\
\hline \multirow[t]{2}{*}{ Age } & 0.1034 \\
\hline & $(0.0006)$ \\
\hline \multirow{2}{*}{ Age-squared } & -0.0013 \\
\hline & $(0.0000)$ \\
\hline \multirow[t]{2}{*}{ Single household } & -0.0191 \\
\hline & $(0.0045)$ \\
\hline \multirow[t]{2}{*}{ Family size } & 0.0045 \\
\hline & $(0.0016)$ \\
\hline \multirow[t]{2}{*}{ No children in housel } & -0.0896 \\
\hline & (0.0049) \\
\hline \multirow[t]{2}{*}{ Number of children il } & -0.0793 \\
\hline & $(0.0025)$ \\
\hline \multirow[t]{2}{*}{ Constant } & -0.4094 \\
\hline & $(0.0156)$ \\
\hline Observations & $1,547,920$ \\
\hline Psuedo R-squared & 0.0956 \\
\hline
\end{tabular}

Notes: Sample includes all nurses or health professionals in the 1990 and 2000 Census (5\% sample) and 2006-2012 ACS. Robust standard errors in parentheses. 
Table A5. Effect of Residing in and Bordering Compact State

Robustness for Difference-in-Differences with Nurses

\begin{tabular}{|c|c|c|c|c|c|c|}
\hline & $\begin{array}{l}\text { Base model } \\
\text { (1) }\end{array}$ & $\begin{array}{c}\text { No controls } \\
(\angle)\end{array}$ & $\begin{array}{c}\text { State X Year } \\
\text { FE } \\
\text { (3) }\end{array}$ & $\begin{array}{l}\text { Only NLC } \\
\text { states } \\
\text { (4) }\end{array}$ & $\begin{array}{l}\text { Only treated } \\
\text { counties } \\
\text { (b) }\end{array}$ & $\begin{array}{l}\text { Cluster by } \\
\text { county } \\
\text { (b) }\end{array}$ \\
\hline \multicolumn{7}{|c|}{ Panel A. In labor force (mean $=.895)$} \\
\hline $\begin{array}{r}\text { Coeff } \\
(\mathrm{SE})\end{array}$ & $\begin{array}{l}-0.0072 \\
(0.0066)\end{array}$ & $\begin{array}{l}-0.0069 \\
(0.0064)\end{array}$ & $\begin{array}{c}0.0155 \\
(0.0131)\end{array}$ & $\begin{array}{c}0.0020 \\
(0.0070)\end{array}$ & $\begin{array}{c}0.0114 \\
(0.0245)\end{array}$ & $\begin{array}{l}-0.0072 \\
(0.0060)\end{array}$ \\
\hline \multicolumn{7}{|c|}{ Panel B. Employed (mean $=.877$ ) } \\
\hline $\begin{array}{r}\text { Coeff } \\
(\mathrm{SE})\end{array}$ & $\begin{array}{l}-0.0117 \\
(0.0071)\end{array}$ & $\begin{array}{l}-0.0119 \star \\
(0.0069)\end{array}$ & $\begin{array}{c}0.0075 \\
(0.0150)\end{array}$ & $\begin{array}{l}-0.0054 \\
(0.0075)\end{array}$ & $\begin{array}{l}-0.0060 \\
(0.0240)\end{array}$ & $\begin{array}{c}-0.0117^{\star *} \\
(0.0058)\end{array}$ \\
\hline \multicolumn{7}{|c|}{ Panel C. Usual hours worked (mean $=34.45$ ) } \\
\hline $\begin{array}{r}\text { Coeff } \\
\text { (SE) }\end{array}$ & $\begin{array}{l}-0.2956 \\
(0.3180)\end{array}$ & $\begin{array}{l}-0.2049 \\
(0.3332)\end{array}$ & $\begin{array}{c}0.0975 \\
(0.6728)\end{array}$ & $\begin{array}{l}-0.0065 \\
(0.4323)\end{array}$ & $\begin{array}{c}0.8767 \\
(1.2721)\end{array}$ & $\begin{array}{l}-0.2956 \\
(0.2868)\end{array}$ \\
\hline \multicolumn{7}{|c|}{ Panel D. Log (wage income) $($ mean $=10.39)$} \\
\hline $\begin{array}{r}\text { Coeff } \\
(\mathrm{SE})\end{array}$ & $\begin{array}{l}-0.0431^{*} \\
(0.0217)\end{array}$ & $\begin{array}{l}-0.0432 \\
(0.0261)\end{array}$ & $\begin{array}{l}-0.0441 \\
(0.0437)\end{array}$ & $\begin{array}{l}-0.0292 \\
(0.0293)\end{array}$ & $\begin{array}{l}-0.0465 \\
(0.0780)\end{array}$ & $\begin{array}{l}-0.0431^{*} \\
(0.0223)\end{array}$ \\
\hline \multicolumn{7}{|c|}{ Panel E. Work in different state (mean $=.0674$ ) } \\
\hline $\begin{array}{r}\text { Coeff } \\
(\mathrm{SE})\end{array}$ & $\begin{array}{l}-0.0201 \\
(0.0122)\end{array}$ & $\begin{array}{l}-0.0200 \\
(0.0122)\end{array}$ & $\begin{array}{c}-0.0498^{\star \star \star} \\
(0.0125)\end{array}$ & $\begin{array}{l}-0.0207^{\star} \\
(0.0109)\end{array}$ & $\begin{array}{l}-0.0381 * \\
(0.0193)\end{array}$ & $\begin{array}{l}-0.0201^{*} \\
(0.0117)\end{array}$ \\
\hline \multicolumn{7}{|c|}{ Panel F. Work in different compact state (mean $=.012$ ) } \\
\hline $\begin{array}{r}\text { Coeff } \\
(\mathrm{SE})\end{array}$ & $\begin{array}{c}0.0220 * * \star \\
(0.0071)\end{array}$ & $\begin{array}{l}0.0221^{\star \star \star} \\
(0.0070)\end{array}$ & $\begin{array}{l}0.0426 * \star \star \\
(0.0150)\end{array}$ & $\begin{array}{c}0.0265^{\star \star \star} \\
(0.0082)\end{array}$ & $\begin{array}{c}0.0085 \\
(0.0239)\end{array}$ & $\begin{array}{c}0.0220 \star \star \star \\
(0.0072)\end{array}$ \\
\hline \multicolumn{7}{|c|}{ Panel G. Log(Commute time) (mean $=3.056)$} \\
\hline $\begin{array}{r}\text { Coeff } \\
\text { (SE) }\end{array}$ & $\begin{array}{c}-0.0536^{\star *} \\
(0.0256)\end{array}$ & $\begin{array}{l}-0.0483^{*} \\
(0.0283)\end{array}$ & $\begin{array}{c}0.0160 \\
(0.0260)\end{array}$ & $\begin{array}{l}-0.0261 \\
(0.0246)\end{array}$ & $\begin{array}{c}-0.1051^{\star * *} \\
(0.0313)\end{array}$ & $\begin{array}{c}-0.0536^{\star \star *} \\
(0.0184)\end{array}$ \\
\hline Observations & 127,633 & 127,633 & 127,633 & 36,919 & 18,295 & 127,633 \\
\hline Number of states & 44 & 44 & 44 & 22 & 16 & 44 \\
\hline Number of counties & 189 & 189 & 189 & 70 & 38 & 189 \\
\hline
\end{tabular}

Notes: Each cell presents the coefficient and standard error on an indicator for living in and bordering a compact state from a separate regression. All specifications include year fixed effects, county fixed effects, and (except column 2) full controls. Controls include indicators for LPN, male, race category, education category, a quadradic in age, indicators for single family household, number of children, and no children under the age of 5, family size (linear), naturalized citizen, and non-citizen. Standard errors clusted by state (county in specification 6) in parentheses. Sample includes all nurses in the 186 counties on state borders that are identified in the Census and ACS and have nurses in the sample. Reported sample size is for Panels A and B. Subsequent panels have smaller sample sizes as they are conditional on being employed or having positive income. ${ }^{\star \star \star} p<0.01,{ }^{\star \star} p<0.05,{ }^{*} p<0.1$ 
Table A6: AHA Summary Statistics

\begin{tabular}{|c|c|c|c|}
\hline & Entire Sample & $\begin{array}{c}\text { One-year Before } \\
\text { Compact }\end{array}$ & $\begin{array}{c}\text { One-year After } \\
\text { Compact }\end{array}$ \\
\hline In a Compact State & 0.11 & & 1.00 \\
\hline Treatment & 0.03 & & 0.23 \\
\hline Full-time Equivalent RNs & 183.20 & 153.93 & 160.58 \\
\hline Full-time Equivalent LPNs & 24.84 & 24.90 & 23.98 \\
\hline Full-time Equivalent Total Nurses & 208.04 & 178.83 & 184.56 \\
\hline RN/Admission & 0.03 & 0.03 & 0.03 \\
\hline LPN/Admission & 0.02 & 0.01 & 0.02 \\
\hline Total Nurses/Admission & 0.05 & 0.04 & 0.05 \\
\hline In a System & 0.53 & 0.54 & 0.57 \\
\hline For-profit & 0.20 & 0.21 & 0.50 \\
\hline Not-for-profit & 0.52 & 0.50 & 0.22 \\
\hline Government & 0.28 & 0.29 & 0.28 \\
\hline Admissions (Adjusted) & 9507.71 & 8206.99 & 8605.79 \\
\hline Total Beds & 162.20 & 142.68 & 139.53 \\
\hline Total In-Patient Days & 39671.89 & 34022.73 & 33485.75 \\
\hline Observations & 92,488 & 2,271 & 2,272 \\
\hline
\end{tabular}

